\title{
"A Scholar and a Gentleman": The Problematic Identity of the Scientific Practitioner in Early Modern England
}

\section{Citation}

Shapin, Steven. 1991. "A scholar and a gentleman": The problematic identity of the scientific practitioner in early modern England. History of Science 29: 279-327.

\section{Published Version}

http://www.shpltd.co.uk/hs.html

\section{Permanent link}

http://nrs.harvard.edu/urn-3:HUL.InstRepos:3595955

\section{Terms of Use}

This article was downloaded from Harvard University's DASH repository, and is made available under the terms and conditions applicable to Other Posted Material, as set forth at http:// nrs.harvard.edu/urn-3:HUL.InstRepos:dash.current.terms-of-use\#LAA

\section{Share Your Story}

The Harvard community has made this article openly available.

Please share how this access benefits you. Submit a story.

Accessibility 
Hist. Sci., xxix (1991)

\title{
"A SCHOLAR AND A GENTLEMAN": THE PROBLEMATIC IDENTITY OF THE SCIENTIFIC PRACTITIONER IN EARLY MODERN ENGLAND
}

\author{
Steven Shapin \\ University of California at San Diego
}

In a small parish church in Fladbury, Worcestershire, there is a funerary plaque commemorating a local Anglican minister who died in 1783, though the plaque itself may date from some years later. The inscription describes him as "a Gentleman, a Scholar, and a Christian". Three years ago I found the plaque noteworthy enough to photograph, and I have been trying ever since to articulate why I found it so interesting. "A Gentleman, a Scholar, and a Christian" - possibly I found it remarkable because of the stranger's natural curiosity: I have not the good fortune to be any one of those things, let alone all three. Perhaps because, though the phrase is and has been for many years a commonplace, I had not at the time noticed it in materials relating to research I had been doing on seventeenth century English scientific culture and its social setting. I thought there might be some significance in that observation.

So far as I now can tell, the commonplace which applauded an individual as a "gentleman, a scholar, and a Christian", and which implied that the attributes of one enhanced or supported the others, emerged in English usage sometime around the last quarter of the eighteenth century. For reasons I shall note below, I did not feel that the 'gentleman and Christian' conjunction was as interestingly problematic, or as under-explored, as that juxtaposing the 'gentleman and scholar', and I set about some unsystematic investigation of the latter usage. Standard reference sources record Robert Burns using it in his Kilmarnock poems of 1786 - "His lockèd, letter'd, braw brass collar,/Shew'd him the gentleman an' scholar" (though the individual concerned was not a man but one of The twa dogs) - as, more influentially, did William Wordsworth, referring to Cambridge college fellows, in The prelude (ix. 227) of 1805: "Brothers all/In honour, as in one company,/ Scholars and gentlemen." $\mathrm{My}$ own reading has turned up a few further usages not generally known, mostly dating from the late eighteenth century. ${ }^{2}$

The formula possibly developed through the nineteenth century in association with Newmanite educational philosophy and the muscular Christian and Romano-classical culture of the great Victorian public schools. ${ }^{3}$ Going back in time through the eighteenth century, references to "the gentleman and the 
scholar" seem to become more sparse, and, by the seventeenth century, they appear very rarely, if at all. An alert and provoked friend drew my attention to a late seventeenth century description of the poet Hugh Crompton $(f .1657)$ as "born a Gentleman and bred up a Scholar". ${ }^{4}$ On closer inspection, however, the message is that Crompton was born into a comfortable landed family, but that his father fell on evil times, and the son was obliged to earn his living by his wits - as a scholar. A contrast is indicated between the two roles rather than (the more modern usage) an approving gesture towards two compatible and mutually supporting dimensions of an individual. Indeed, I have persuaded myself that the usage with which we are familiar did not exist, and certainly not as a commonplace, in the late sixteenth or seventeenth century. Nevertheless, I neither wish nor need to argue a null hypothesis. While I am reasonably confident in my impression about the temporal distribution of the usage, the main thrust of my argument proceeds through an assessment of publicly voiced sixteenth and seventeenth century English attitudes towards the attributes of the gentleman and the scholar. ${ }^{5}$

There are two general and one specific reasons why I thought it worthwhile to offer this preliminary archaeology of 'the gentleman and the scholar'. Firstly, although historians now intermittently make gestures towards informal theories of cultural change as bricolage, I want to offer a detailed exploration of the ways in which very old and pervasive cultural topics are artfully re-combined and re-valued in processes of social change. The topics with which I am concerned include themes thoroughly familiar to cultural historians, for example, enduring normative specifications of the happy and virtuous life as belonging either to the public or the private sphere. I show how the very stability of these topics over time meant that they constituted powerful resources and valuable prizes for actors vying for their proprietorship and the right to interpret them. In order to signal my view that such topics are storehouses of tools for social action, I refer to relatively stable packages of attributions and evaluations as repertoires. ${ }^{6}$ And I want to argue that the use of these repertoires in social action worked further to entrench their stability. I note that specific early modern descriptions and evaluations of the characters of scholars and gentlemen have ancient sources, and I devote some attention to the sixteenth century humanist background to seventeenth century initiatives which sought, by reforming a body of culture, to re-specify the identity of both gentlemen and scholars. I display the restricted materials with which cultural innovators work and the recombination of which constitutes the cultural dimensions of social change.

Secondly, I want to contribute to and extend a traditional body of sociological theory dealing with the relations between culture and institutional change. Historians and sociologists of science are familiar, for example, with Robert Merton's views on the institutionalization of the new science in 
seventeenth century England. Merton here followed Max Weber in arguing that institutionalization proceeded by attaching yet-to-be-legitimated social practices to major reservoirs of legitimacy in the local culture. The new science, in Merton's materials, was obliged to display its standing vis-à-vis predominantly religious values. If it could do that, then it might become institutionalized, and, ultimately, a value in its own right. This general view of institutionalization is undoubtedly correct, valuable and under-exploited by cultural and social historians. By extension, it amounts to a programme of research into legitimation and social order, an inquiry into how culture is constituted by the stock of available legitimations for social practices, and a framework for assessing the constitution of culture as locally situated repertoires for managing social stasis and prompting social change. ${ }^{7}$

More recently, Quentin Skinner has attempted to merge Weberian views of legitimation and social action with the insights of analytic philosophy. Situated repertoires (my puffed-up version of what Skinner calls "evaluativedescriptive terms") define the domains of legitimacy and illegitimacy in any culture. If actions and roles are to be legitimated, this must happen in some contextually specific way. The range of application of the repertoires at any time defines, as it were, normal practice, and the cultural innovator must, in giving the repertoires new and particular reference, work to constitute a different extension. Skinner plausibly speculates that the institutionalized uses of these repertoires constitute practical resistances to innovatory social action. Whatever the innovator may intend, he "cannot hope to stretch the application of the existing principles indefinitely; correspondingly, he can only hope to legitimate a restricted range of actions". 8

Freely conceived this way, the Weber-Merton-Skinner theory needs only minor modification and empirical development. It is, of course, unlikely that any society can be associated with a single value system, or, indeed, that the articulation of such values in situated legitimations is straightforward and uncontested: there are likely to be many possible paths from values to justifications for courses of action. If the value is, for instance, 'being useful', there are probably no institutionalized social practices which cannot argue their utility, though the local effectiveness of such arguments, as Skinner suggests, will be a highly contingent matter. Accordingly, I suggest, it is implausible that there is any such thing as a crucial or irresistible legitimation - one which is bound to work and to which there is no effective riposte and idealist approaches to the relations between culture and social action are likely to look less credible as historical inquiries become more detailed.

My specific interest concerns the cultural resources available for legitimating the new scientific practices of seventeenth century England, the use of relevant repertoires in justifying (and condemning) the new science, and the practical consequences of those cultural manoeuvres. In the particular case at 
hand, there is little question that Puritan strands of religion provided important sources of legitimacy for many groups in seventeenth century English society, even, especially, for those groups which offered significant support and approval to the new cultural forms of empirical and experimental natural philosophy. There were, however, other sources of legitimacy in contemporary English society, and among the most consequential of these for the new science was the pervasive and quite traditional culture which specified who gentlemen were, how it was proper for them to live and behave among their fellows, and how the gentlemanly role stood with respect to various forms of cultural practice and their practitioners.

I shall argue that a major (and, perhaps, the major) problem for the proponents of the new scientific practice was the exhibition of its suitability for a gentleman. And insofar as legitimacy was to be sought through a display of the new science as genteel, then a further, more negative, task was also implicated: in that setting it had to be shown that the new knowledge was not just another form of traditional learning and that its practitioners were not just traditional scholars. In seventeenth century England what was understood of gentlemen and what was understood of scholars set them in opposition. The story that Merton told ended in rapid triumph; this story, by contrast, does not really end at all. I shall show that the new science secured little legitimacy within seventeenth or eighteenth century gentlemanly society. Indeed, it is far more likely that the new science ultimately secured what legitimacy it did partly by processes of intercalation into existing roles for the learned and partly by the gradual development of new sources of support and approval outwith genteel society.

The paper has three parts: in the first, I argue (against some apparent evidence to the contrary) that both the ascribed attributes and aspects of the concrete circumstances of the gentleman and the scholar set them in opposition; in the second, I show that the publicists of the new science attempted to develop a scholarly practice suitable for gentlemen, in the course of which they aimed to re-specify what it was to be a gentleman and what it was to be a scholar; finally, I analyse the obstacles confronted in that attempted respecification, and I ask what the new scientific enterprise looked like from the point of view of genteel society. To this end I turn to sources not commonly used by historians of science and philosophy - the so-called 'courtesy' literature which detailed codes of practical conduct and manners for gentlemen. ${ }^{9}$

\section{THE SCHOLAR AND THE GENTLEMAN}

There is no reason to deny much evidence from sixteenth and seventeenth century England which seems to suggest an environment favourably disposed 
to the conjunction of the gentleman and the scholar. Although classical resources were mainly mobilized to condemn the excessively solitary and sequestered nature of the scholar's and philosopher's lives, Tudor and Stuart social commentators occasionally pointed to Greek and Roman patterns which identified similar bases for gentle and learned lives. The institucion of a gentleman (1555) went so far as to assert that the very idea of nobility originated in an ancient learned class. ${ }^{10}$ Some neo-Stoicists argued that the defining characteristics of the gentleman were his integrity and independence. The gentleman wanted and depended upon nothing external to himself - nil admirari. The philosopher too needed less of the world's goods, its applause or sustenance. Indeed, he provided his own company, established and conversed with his own society, within the privacy of his mind. Thus, an early seventeenth century English translator of Epictetus noted that

It is a true marke of vulgar basenesse, for a man to expect neither good nor harme from himselfe, but all from externall euents. Contrariwise, the true note of a Philosopher, is to repose all his expectation, vpon himselfe alone. ${ }^{11}$

More pervasively, sixteenth century English humanist writers (e.g., Thomas More, Thomas Elyot, Lawrence Humphrey, Roger Ascham) strenuously argued that learning was appropriate for those of gentle standing, that gentlemen required learning to acquit their duties to king and country, and that gentlemen might legitimately be recognized through their cultural accomplishments. ${ }^{12}$ Both Erasmian and Italian humanist models acquired an avid following in England. Arguments in favour of genteel learning appeared in highly practical courtesy literature as well as in texts of more elevated tone. The translator of Stefano Guazzo's Civile conversation made the point most forcibly:

You will be but ungentle gentlemen, if you be no Schollers. ... Therefore (gentlemen) never deny your selves to be Schollers, never be ashamed to shewe your learnyng, confesse it, professe it, imbrace it, honor it; for it is only it which honoureth you, it is only it which maketh you men, it is onely it which maketh you Gentlemen. ${ }^{13}$

Castiglione's Book of the courtier urged the case for regarding "letters", besides virtue, as "the true and principal adornment of the mind". ${ }^{14}$ In England, as in Urbino, "a noble mind" expressed itself in "The courtier's, soldier's, scholar's, eye, tongue, sword". ${ }^{15}$ An Interregnum courtesy text went so far as to claim that "knowledge ... must be the principal accomplishment of the Gentleman". ${ }^{16}$ John Cleland's influential The instruction of a young nobleman argued a utilitarian case for learning. It fitted a man to be his prince's valued counsellor, to take active part in public life, to be an effective military 
leader: "A learned Courtier is capable of his Maiesties profound discourses at al times." Learning also assisted genteel voluptuousness. A well-read and wellspoken gentleman "can court the ladies with discretion and intertaine them in wise and honest conference"; an ignorant courtier "maketh the chamber maids laugh at his discourses ...".17 The rich cabinet noted the power of learning in maintaining the station of the well-born and in advancing that of the humbly born: by its aid "men of base parentage haue come to place of high preheminency". ${ }^{18}$ English Puritan courtesy writers, otherwise suspicious of "prideful" learning, persistently argued a case for learning as antidote to genteel indolence: "Learning hee holds not only an additament, but ornament to Gentry. No compliment gives more accomplishment. He intends more the tillage of his minde, than his grounde ...."19 In 1622 Henry Peacham's The complete gentleman came as close as any early seventeenth century English text to mobilizing a coherent vision of what the 'gentleman-scholar' might look like. Since learning "is an essential part of nobility ..., it followeth that who is nobly born and a scholar withal deserveth double honour...". Learning polished "inbred rudeness"; helped one to live with "honor" and "dignity"; moderated the brutish passions. Largely through the example of Peacham and the Arundel circle which provided his patterns, "virtuosity" became an increasingly common vehicle for the self-fashioning of the English gentleman in the seventeenth century. ${ }^{20}$

Sentiments approving of learning were accompanied by significant shifts in the exposure of the gentry and aristocracy to the institutions of higher education - the universities and Inns of Court. The Tudor Revolution in government provoked widespread recognition among the gentry that their neglect of learning might result in the loss of effective political power to ambitious and humbly-born clerks. ${ }^{21}$ For these and other reasons, the period from $c .1580$ to $c .1640$ saw very substantially increased demand from the gentry for the intellectual and moral goods purveyed at Oxford and Cambridge. The growth in university enrolments as a whole, and the rising proportion of matriculants from the gentry and aristocracy, have been well documented. ${ }^{22}$ If, at the beginning of the sixteenth century it was true that the universities "were little more than seminaries for the education of the clergy of the Established Church", by the early seventeenth century, according to Curtis, "the academic haunts of the medieval clergy had become a normal resort for the sons and heirs of the English gentry and nobility". ${ }^{23} \mathrm{~A}$ university education became the norm for the great crown servants of the Elizabethan era - the Cecils, the Bacons, and their like. ${ }^{24}$ And while Kearney reckons that the clerical character of the universities was not wholly lost but only diluted during the sixteenth and seventeenth centuries, there is little doubt that the English gentry made an increasing mark upon institutions of higher education and that, as Stone puts it, they were, in significant measure, "converted" by the 
“A SCHOLAR AND A GENTLEMAN” · 285

humanists' arguments. ${ }^{25}$ As a gentleman wrote to the Master of St John's, Cambridge in 1614, upon sending his son up to university, "my greatest care hitherto hath bene, and still is, to breed my sonne a scholar". ${ }^{26}$

Moreover, there is evidence that the universities responded to the gentlemanly influx by changing the goods they had to offer their students. Modern subjects and a curriculum less orientated to the needs of future clerics were gradually introduced. As early as 1550 Hugh Latimer exaggerated that "there be none now but great men's sons in the colleges, and their fathers look not to have them preachers". ${ }^{27}$ In the middle of Elizabeth's reign Gabriel Harvey observed that Cambridge scholars were becoming "active rather than contemplative philosophers" and that they were reading such practical and worldly works as Castiglione's Courtier and Guazzo's Civile conversation. Later on, Peacham's conception of the virtuoso became modish, and the landed aristocrat in early seventeenth century Oxford might take advantage of lessons in riding, dancing and vaulting. ${ }^{28}$ In the 1620s John Earle described "A meer yong Gentleman in the university" as one whose "father sent him thither, because he heard there were the best dauncing and fencing schooles; from those he has his education ...". ${ }^{29}$ And in the 1650s no less a person than the Oxford professor of astronomy defended the universities from sectarian attack by denying that the gentry expected them to teach their sons materially useful knowledge: "the desire of their friends is ... that their reason, and fancy, and carriage, be improved by lighter Institutions and Exercises, that they may become Rationall and Graceful speakers, and be of an acceptable behaviour. ..."30 The argument that sixteenth century humanists are said to have 'won' concerned the definition of 'nobility' or 'gentility'. Nobility was now very widely said to consist not only in birth but also in 'virtue'. And virtue was not only a matter of piety and morality but also, as Stone notes, "the mastery of certain technical proficiencies", among which were now counted a degree of "book-learning". ${ }^{31}$

That is one story: during the course of the sixteenth and early seventeenth century learning triumphed over ignorance, as braying hordes of rising gentry tramped through the scholar's study and emerged on the other side canny, smooth and virtuous. Another, more negative, story is more difficult to summarize and make coherent. Firstly, the real changes which occurred in Tudor and Stuart conceptions of the gentleman were matters of degree, and the degree to which they turned traditional patterns upside down looks to have been overstated. Secondly, much of what has been rightly noted of 'learning' and the universities in relation to the gentry does not in fact simply translate into the constitution of a 'gentleman-scholar' as a recognized role in sixteenth and seventeenth century English culture. And most importantly, through the seventeenth century, and into later periods, that culture continued to be informed by a pervasive sensibility about what scholars and the scholarly life 
were like - a sensibility that persistently worked against approval of commitment to deep or systematic learning in gentlemanly society.

Portrayals of the English gentleman as ignorant and proud of it were hardly new in the sixteenth century: what was new was the notion that things might be otherwise. ${ }^{32}$ Nor did those depictions disappear with the humanist 'victory' described above. Both the rustic squire and the urban gallant of Restoration comedy testify to the limited extent of humanist success: the one was defiantly unlettered and the other used what learning he had in the cause of dissipation. For all that has been written about the exposure of the English gentry and aristocracy to the world of learning, the impact of scholarly goals and values upon gentlemanly polite culture was circumscribed. The tide which increasingly swept the gentry into the universities had, in any case, run out by the Restoration. Despite complaints that the aristocracy were pushing poor scholars out of the colleges, the evidence suggests that the proportion of gentlemen and above never rose much over $50 \%$, and after 1660 the lesser gentry in particular again regarded higher education with a jaundiced eye, reluctant to rub shoulders with their social inferiors. According to Anthony à Wood, they thought "an University too low a breeding". ${ }^{33}$

Moreover, it would be wrong to infer from the "astonishing explosion of higher education in England" that what the gentry wanted from the university was that for which the university had traditionally been known. In 1561, his son about to go up to university, William Cecil said "I mean not to have him ... scholarly learned but civilly trained ...". The universities were merely becoming places where it was more and more possible for 'civil training', practical learning and polite accomplishments to be acquired, if that was what was wanted. ${ }^{34}$ Nevertheless, through the seventeenth century the universities continued vigorously to fulfil their traditional functions of training clerics and sustaining scholarship. Among other things this meant that the universities were sites where several cultures came briefly into contact before - in the main - going their separate ways. The gentry's elder sons passed through the university on their way to succession and/or crown service; the poor secured training as clerics, or, if exceptionally able and lucky, ultimately rose through the ranks to join their betters; and the fellowship and professoriate, augmented by the most able students wishing to become 'gown-men', maintained institutional and cultural continuity. ${ }^{35}$ The external social landscape was inscribed within the colleges. 'Scholars' and 'fellows' on the college establishment were generally of plebeian origin while aristocratic 'commoners' and 'gentlemencommoners' paid their way and used their inferiors as 'battelers' and 'servitors' ${ }^{36}$ Thus, the contours of social standing very roughly followed the boundaries between those who were professionally committed to a scholarly life and those who were not. 
“A SCHOLAR AND A GENTLEMAN" · 287

\section{A SCHOLAR AND A PEDANT}

In sixteenth and seventeenth century usage, the term 'scholar' might refer to individuals fulfilling several loosely related but different roles. Most generally, the 'scholar' could be anyone who received his instruction from an acknowledged 'master'. Any child or young person undergoing a course of education (privately or publicly) might be counted a 'scholar'. The term could (as an evaluative discrimination) designate someone in the process of being educated who was notably able, or (in the administrative sense mentioned above) who received emoluments from the institution by virtue of his abilities. It might more specifically refer to someone whose learning was considered to be especially extensive or deep, whatever his means of support; and, finally, it might indicate someone professionally engaged in the pursuit or transmission of knowledge, particularly in institutions of higher education. ${ }^{37}$ The problems set by contemporary culture for the role of the 'gentleman-scholar' pertain very largely to the last two usages.

Frictions between sixteenth and seventeenth century conceptions of the attributes of the gentleman and those of the scholar were the actively sustained and occasionally contested legacies of Antiquity. They were inherited from Greek and Roman repertoires concerning the form of life that was desirable for citizens and that which was expedient or even necessary for those giving their lives over to the search for truth. Aristotle argued for the natural sociability of man and for the responsibility all citizens bore to the polis, while recognizing that philosophers might effectively pursue their quest separated from society. Cicero sharpened the evaluative contrast between the active and contemplative lives, providing one of the most important medieval and early modern resources approving civic commitment and condemning the wholly withdrawn contemplative life. And, while monasticism provided the sequestered intellectual with sites, roles and justifications, Christian patterns deepened the divide between the perceived attributes of the clerk and the citizen or knight. ${ }^{38}$

Through the late Middle Ages and early modern period a view of the scholar crystallized in secular aristocratic culture that pervasively identified his character and way of life as incompatible with those of the gentleman. ${ }^{39}$ While genteel society did on occasion express great respect for scholarly goods (and in the case of sacred scholarship was formally bound to do so), the attributes of a scholar and those of a gentleman were increasingly seen in opposition. Aspects of that opposition derived from social geography. Early medieval society was marked by a deep social gulf separating the world of the learned (or even the lettered) from that of the gentleman or aristocrat. Those who bore and transmitted literate knowledge were a small minority of the population, and they were almost always clerics. Towards the end of the fourteenth 
century the monastery and the university lost their monopoly as centres of literate culture, and, while literacy and a degree of learning now became more common courtly attributes, the professional intellectual was even more separated from political life and mundane society. Scholars - both sacred and secular - generally lived in worlds removed from those of the court or the exchange; their identities, as well as the meaning and worth of their intellectual goods, were associated with their contemplative sequestration. The late fifteenth and early sixteenth century saw the strong development, particularly in some Italian, central, and northern European states, of court patronage and a courtly setting for philosophical and mathematical scholars. Important studies by Moran, Westman, and, especially, Biagioli have shown how significant client-patron relations at court became for some Renaissance careers in the sciences. ${ }^{40}$ Nonetheless, patterns revealed by the study of a small number of scientific clients do not equate with the overall appreciation of the scholar by polite and courtly society. While some professional scholarly lives did indeed depend crucially upon court patronage - Galileo's is now one of the best studied - professional scholars' claims to gentility and civic utility were scarcely widely acknowledged or endorsed in the writings of European courtiers about the relationship between learning and the noble life. Even at the height of the humanist movement in the sixteenth century professional intellectuals were still routinely associated with sites separated from secular society. ${ }^{41}$

The scholar was also distinguished from the gentleman by facts of economic life. Clerks were largely recruited from the common people, and remained poor in relation to simple gentlemen and aristocrats. While the upper echelons of the clergy might accumulate vast wealth, both the clerical scholar and the university fellow or professor of the Middle Ages or early modern period were noted for their relatively humble origins, for their poverty, and for their routinely expressed disdain of worldly goods. ${ }^{42}$ In the early sixteenth century an English diplomat observed that learned men were "beggars" and that he would rather see his son hanged than learned. A century later a courtesy text noted that "A scholar is an enemy of fortune". James Cleland lamented that "manie growing in yeares professe nothing more than scoffing at learning \& the professors therof, in calling them al clerks or pedants. If they perceiue anie Noble man better disposed to learning then themselues, presentlie after a scorning manner they wil baptize him with the name of Philosopher." And the Jacobean physician Robert Burton complained that the scholar's life was esteemed base and mean, "and no whit beseeming the calling of a Gentleman". ${ }^{43}$ While the opposition between the scholar and the gentleman referred to social and economic facts, it was expressed in a set of repertoires which spoke of both scholars' and gentlemen's temperamental, moral and social characteristics. Those repertoires formed an important normative resource in 
medieval and early modern Europe, allowing the simultaneous judgment of virtue and cultural value, of appropriate conduct and appropriate knowledge.

While the definition and justification of gentle standing were highly contested throughout early modern Europe, there was little disagreement concerning the overall mode of conduct to which the gentleman was enjoined.44 Firstly, he was to live in society and to take part in its affairs; he was not to live for himself but for others; he was to express his valour in his selflessness, whether on the field of battle or in civic settings. Secondly, he was in all things to seek to please his fellows, adapting his behaviour to his circumstances. In contemporary parlance, the preference was for an 'active' rather than a 'contemplative' life for those of gentle standing, negotium rather than otium; and the terms used to designate measured and contextually appropriate behaviour were decorum and courtesy. The gentleman was to avoid excess in all things; to exercise self-control; to avoid opinionated and verbose behaviour or the visible effort to press his own views on his fellows. If he wished to dominate, he must do so through studied effortlessness and agreeableness. The quest for fame must seem like its nonchalant denial. Everything he did must express magnanimity. His conduct must work to uphold social harmony and the presumed equality of gentle society; nothing he did should divide, disrupt or disturb. Conduct must be fitted to social circumstance, and the art of doing so ought to appear utterly artless. Affectation and ostentation were to be avoided at all costs. Castiglione's influential version identified decorum as tacit knowledge: "I think it difficult to give any rule in this. ... [W] hoever has to engage in conversation with others must let himself be guided by his own judgment and must perceive the differences between one man and another, and change his style and method from day to day, according to the nature of the person with whom he undertakes to converse." 45 And Guazzo's humanism aimed at "civile conversation", "an honest, commendable and vertuous kinde of living in the world". Decorum was at once means and end: "Wee must yeelde humbly too our Superiour, perswade gently with our inferior, and agree quietly with our equall. And by that meanes there shall never bee any falling out." 46

The identification of gentlemanly decorum and active engagement in the world provided a sharp contrast to attributions of scholars' temperament and mode of life. Aristotle asked why it was "that all men who have become outstanding in philosophy ... are melancholic", and concurrence that they were morose and withdrawn echoed through medieval and early modern culture. While early Christian thinking condemned the melancholic temperament and its "disordered wanderings of the imagination", a more approving attitude emerged in the late Middle Ages. Melancholia and attachment to solitude became for many intellectuals a recognized mode of self-presentation, "a way of feeling and being" that identified the intellectual and that vouched 
for the authenticity of his cultural goods. ${ }^{47}$ In this respect, a withdrawn and depressive persona marked out the intellectual in cultural space and constituted an understood token of the value of his knowledge, while contrasting his character and circumstances to those of the actively engaged public citizen. Throughout early modern Europe the portrayal of the scholar and philosopher as solitary melancholics was an institution in social commentary, medicine, poetry and painting. ${ }^{48}$

The scholar's melancholic temperament and solitary situation were widely mobilized as explanations of the most damaging attribution about his character. Throughout early modern Europe professional scholars were characterized as pedants. The characters of the pedant and the gentleman were set in radical opposition. Indeed, in the courtesy literature and practical social philosophies of early modern Europe the disposition and deportment of the pedant appeared as a practical inversion of the gentlemanly character. The root meaning of 'pedant' was simply someone who taught, who acted as a pedagogue. This neutral usage is still found in late sixteenth century England, ${ }^{49}$ but, as time went on, to say that someone was a pedant was invariably to identify a deeply damaged and unsatisfactory character.

What were the characteristics of the pedant considered to be in sixteenth and seventeenth century England? He was someone whose manner was disputatious, litigious, affected and hectoring; he lectured rather than conversed. He was selfish, aiming not to please but to dominate. He was, thus, deficient in the key gentlemanly virtue of magnanimity. He was both temperamentally unbalanced and the source of discord in company; his gravity and melancholia annoyed and disturbed; his disputatiousness subverted social harmony and order. He was obsessively concerned with matters of little interest to polite society. He was ill-mannered, rude and uncivil; living separated from polite society, he could not master its mores and was a figure of fun and ridicule when obliged to enter that world; he might be mad. He was lacking in the knightly virtue of valour; his blind reliance upon ancient authority over prudence was an expression of timidity; he who was a slave to Aristotle was not a free man. Withdrawn study worked against the acquisition of that sense of emulation and responsibility that made men do brave deeds. His objects of study were trivial and ignoble, and, hence, unsuitable for polite conversation. He was a bore. Since his knowledge was based upon books and authority, rather than upon worldly experience, what he knew was impractical, of no use to civil society. For that reason, gentlemanly society might judge the pedant, however learned, to be lacking in sense, a fool, a bookish idiot.

From the sixteenth to the eighteenth centuries condemnation of scholarly pedantry and incivility was pervasive. Montaigne's defence of appropriate learning, for example, proceeded by way of an attack on the pedant. The 
"opinions and ways" of present-day schoolmen and philosophers make them "ridiculous"; they fill their memory but leave their understanding empty:

Just as birds sometimes go in quest of grain, and carry in their beak without tasting it to give a beakful to their little ones, so our pedants go pillaging knowledge in books and lodge it only on the end of their lips, in order merely to disgorge it and scatter it to the winds. ... [I]t passes from hand to hand for the sole purpose of making a show of it, talking to others and telling stories about it. ... I know a man who, when I ask him what he knows, asks me for a book in order to point it out to me, and wouldn't tell me that he has an itchy backside unless he goes immediately and studies in his lexicon what is itchy and what is a backside. ${ }^{50}$

Guazzo poked fun at the learned recluse - "Doe you not thinke that these men may bee called wise by learning, and fooles in respect of the common people" - and precisely similar sentiments about the scholar-pedant were expressed by Montaigne, Burton, Lodowick Bryskett, and many courtesy writers. ${ }^{51}$ Roger Ascham observed that "all Mathematicall heades, which be onely and wholy bent to those sciences" were "unfit to liue with others" and "unapt to serue in the world"; "as they sharpen mens wittes over much, so they change mens maners over sore". ${ }^{52}$ Francis Bacon said that to "spend too much time in studies, is sloth; to use them too much for ornament, is affectation; to make judgment wholly by their rules, is the humour of a scholar". ${ }^{53}$ Montaigne agreed "that the pursuit of learning makes men's hearts soft and effeminate more than it makes them strong and warlike". ${ }^{54}$ Bryskett noted that "we see oftentimes men of great learning in sundry professions, to be nevertheless rude and ignorant in things that concerne their carriage and behaviour". ${ }^{55}$ And John Evelyn, defending the view that knowledge and action ought to go together, granted that it was both true and culpable that philosophers and "our learned book-worms come forth of their Cells with so ill a grace into Company". A life spent wholly "in Theory and Fancy, Extasie and Abstractions" was "fitter for Bedlam ... then for sober men ...". .66

In the Restoration Samuel Butler's satires on the abuse of learning linked "the peccant Humors of Learnd Men" to the circumstances in which the scholarly life was led:

For whether 'tis their want of Conversation, Inclines them to al Sorts of Affectation:

Their Sedentary Life, and Melancholy,

The Everlasting Nursery of Folly;

Their Poring upon Black and White too subtly

Has turnd the Insides of their Brains to Motly ... 
Their Constant over-straining of the minde

Distort[s] the Braine, as Horses break their winde .... ${ }^{57}$

And Burton acknowledged that the polite world considered solitary scholars to be quite mad:

How many poor scholars have lost their wits, or become dizzards, neglecting all worldly affairs and their own health, wealth, being \& well being, to gain knowledge! for which, after all their pains, in the world's esteem they are accounted ridiculous and silly fools, idiots, asses, and (as oft they are) rejected, contemned, derided, doting, and mad! ... Go to Bedlam and ask. ${ }^{58}$

In 1632 John Milton, then a student at Christ's, Cambridge, censured Scholastic pedantry and acknowledged that scholarly solitude was considered to unift the learned for polite society:

Many people ... complain that the learned are often hard to please, rude, poorly trained in manners, and lacking in agreeable speech. ... I admit that a man who is for the most part alone and absorbed in his studies ... is less suited for the finer conventions of social behavior. ${ }^{59}$

In 1651 the Provost of Eton, Sir Henry Wotton, repeated ancient Greek advice to the philosopher "sometimes to offer Sacrifice at the Altars of the Graces", thinking "Knowledg to be imperfect without Behaviour". It was true that deficiencies in manners were the cause of "disrespect to many Scholers [from] Observers of Ceremonies". Indeed, "slovenliness is the worst sign of a hard student, and civility the best exercise of the remiss". Even so, in Wotton's view, the gentleman and the scholar had their separate spheres of appropriate conduct, and it would be wrong to impose on either an alien code: "Somewhat of the Gentleman gives a tincture to a Scholer, too much stains him." 60 And in 1660 a Christian courtesy text pointed to the dilemma faced by university tutors: in "making the Scholar" one is thought to be "spoiling the Gentleman".61

\section{THE REFORM OF LEARNING AND THE END OF PEDANTRY}

While the identification of the scholar with the pedant was quite general in polite Tudor and Stuart society, particular forms of scholarly life and endeavour were marked out for special odium. Literally trivial pursuits grammar, rhetoric and logic, and, by imputation, the whole form and substance of Scholasticism - were increasingly condemned as nothing but pedantry. In the view of those advocating a reform of learning, what was wrong with Scholasticism was that it proceeded from, and fostered, a form of life that was in no way suitable for a civic gentleman. 
Lord Herbert of Cherbury recommended an ordinary course of university study for elder sons, but disapproved of learning the subtleties of logic, "which, as it is usually practised, enables them for little more than to be excellent wranglers, which art, though it may be tolerable in a mercenary lawyer, I can by no means commend in a sober and well-governed gentleman". Oratory was, of course, an important study, yet "I can by no means yet commend an affected eloquence, there being nothing so pedantical ... than to use overmuch the common forms prescribed in schools". The ritual forms of Scholastic disputation publicly dramatized the argumentative and combative character of its practitioners. ${ }^{62}$ Milton criticized the Scholastic curriculum for making students both litigious and useless: "And these are the fruits of mispending our prime youth at the Schools and Universities as we do, either in learning meer words or such things chiefly, as were better unlearnt." Scholastic "ragged Notions and Babblements" were the cause of the current "hatred and contempt of Learning". What Milton called "a compleat and generous Education" was one which fitted a man "to perform justly, skilfully and magnanimously all the offices both private and publick of Peace and War". ${ }^{63}$

The imputation of pedantry and incivility to the traditional scholarly form of life was an important resource in the arguments of those who wished to replace Scholasticism with a new type of knowledge and a new type of knower. Ramists and Paracelsians were not, of course, widely identified with genteel circles, but their condemnation of Scholastic disputatiousness and impracticality associated existing scholarly patterns with acknowledged disqualifications to gentility. ${ }^{64} \mathrm{John}$ Webster's analysis of Scholastic logic-chopping was a catalogue of the recognized vices of pedantry:

a civil war of words, a verbal context, a combat of cunning craftiness, violence and altercation, wherein all verbal force, by impudence, insolence, opposition, contradiction, derision, diversion, trifling, jeering, humming, hissing, braw[1]ing, quarreling, scolding, scandalizing, and the like, are equally allowed, and accounted just ....65

Much sectarian criticism of the universities for their neglect of practical studies (chemistry, agriculture) during the Civil War decades is better understood as the appropriation of widespread humanist sentiments in favour of a civically virtuous and useful life for the gentleman than as advocacy of artisan takeover.

Criticism of Scholastic incivility, uselessness and pedantry was pervasive among seventeenth century 'modern' natural philosophers. Indeed, identification of Scholasticism as unsuitable for the practice or fashioning of a gentleman was a powerful argument in favour of new knowledge and new intellectual institutions. In 1669 Leibniz urged the Duke of Württemberg that a new university be established in an urban setting: 
This may well seem a peculiar view to him who believes in the vulgar maxim that Universities should be situated in quiet solitary places, so that young men should not be disturbed at their studies. ... Yet, to tell the truth, nothing has so much contributed to the spirit of Pedantry ... than just this rule ....

Whenever this "monkish erudition" made its "appearance in the world or in conversation", it constituted little more than an "object of ridicule". ${ }^{66}$ Descartes's Discourse on method recommended self-knowledge and experience over school-philosophy in terms instantly recognizable from sixteenth and early seventeenth century humanist and courtesy literature. Thomas Hobbes systematically excoriated Scholastic universities as places of pedantry, litigiousness and, ultimately, of social subversion. School "Aristotely" bred disputatious men, who were in turn the fulminators of civil strife: "The Universities have been to this nation, as the wooden horse was to the Trojans." Yet "men may be brought to a love of obedience by preachers and gentlemen that imbibe good principles in their youth at the Universities .... [W] shall never have a lasting peace, till the Universities themselves be ... reformed." 67 Schoolmen's discourse was nothing but "canting"; their blind reliance upon authority "is a signe of folly, and generally scorned by the name of Pedantry". ${ }^{68}$

English arguments in favour of a reformed natural philosophy similarly proceeded from the humanist case and its analysis of the malaises of the existing scholarly life. Advocates of the new experimental science in seventeenth century England were simultaneously arguing for a new type of knowledge, a new type of knower, and a new mode of relationship between the knower and what was to be known. If the gentleman was to be re-fashioned through learning, then the world of learning had also to be re-formed to fit it for the task. Such a new form of learning would produce a scholar who suffered from none of the vices of the pedant - a virtuous scholar whose pursuit of knowledge was a civic act, bringing civic benefits. It would, that is, fashion a gentleman-scholar, fit to live in, and to benefit, the polis. ${ }^{69}$

No formulation of this humanist case for new knowledge was as locally potent as Bacon's Advancement of learning. A major theme in Bacon's commendation of proper learning for a gentleman was the evidence of Antiquity when, he said, uncorrupted knowledge was the proud possession of kings and warriors. Genuine knowledge did not "soften men's minds", make them "more unapt for the honour and exercise of arms", or "mar and pervert men's dispositions for matter of government and policy". Instead, properly constituted knowledge nurtured the noble virtues of magnanimity and valour, and fitted men for active and valuable roles in civic life. While it "hath been ordinary with politic men to extenuate and disable learned men by the names 
of Pedantes", yet ancient states flourished best when they were in the hands of truly learned persons. ${ }^{70}$ In fact, Bacon's argument here was a re-specification of a centre-piece of English humanist writing from Thomas Elyot's Governour (1531) onwards. According to Elyot, Alexander the Great "often tymes sayd that he was equally as moche bounden to Aristotle as to his father kyng Philip, for of his father he receyued lyfe, but of Aristotle he receyued the waye to lyue nobly". Who condemned Epaminondas "for that he was excellently lerned and a great philosopher?" Who reproved the Emperor Hadrian "for that he was so exquisitely lerned ... in all sciences liberall?" There was no lack of ancient patterns for "howe much excellent lernynge commendeth, and nat dispraiseth, nobilitie". ${ }^{71}$ What was novel about Bacon's argument was only that it required a radical reform of learning to accomplish the ends that Elyot and other English humanists reckoned could be achieved largely by existing resources.

The alleged "distempers" of learning were, in Bacon's view unjustly, attached to learning itself, constituting real obstacles to the humanist programme for the simultaneous reform of culture and gentry. It was said that learning, as well as making men soft, made them morose, ill-mannered, tumultuous, litigious, and civicly worthless. These distempers were, according to Bacon, the real flaws of a secluded, private, abstract, authoritarian, overly systematic, and disputatious practice. Once these distempers were remedied by a new and purified form of intellectual practice, it would be seen "without all controversy that learning doth make the minds of men gentle, generous, maniable, and pliant to government". Nor was it true that "any disgrace to learning can proceed from the manners of learned men; not inherent to them as they are learned". True, learned men "contend sometimes too far to bring things to perfection", but this was because "the times they read of are commonly better than the times they live in". ${ }^{72}$ And while Bacon strove to resuscitate the civic reputations of ancient Pedanti, he was, of course, perfectly able to point the finger at the "errors and vanities", the "peccant humours", of present-day scholars: the "fantastical", "contentious" and "delicate" forms of Scholastic practice. This was what "traduced" learning as a whole; this was what was responsible for the tension between the very idea of the scholar and the very idea of a gentleman. ${ }^{73}$

THE SCHOLAR, THE GENTLEMAN AND THE EXPERIMENTAL PHILOSOPHER

The establishment of the Royal Society of London was advertised as the practical realization of the humanist-Baconian vision. Here was a real community of gentlemen-scholars, practising a form of inquiry which was suitable for the noble and which ennobled those who practised it. Here at last was an antidote to the distempers of existing intellectual forms which had 
resulted in genteel contempt for learning and the learned. ${ }^{74}$ The Royal Society announced itself to be at once a philosophical community and "a great assembly of Gentlemen"; it actively enlisted the membership and support of the gentry and aristocracy, and it proffered reasons why the new experimental learning was uniquely suitable for English gentlemen. ${ }^{75}$ The objects of the new practice elevated those who participated. The study of nature was not ignoble because it was the de-coding of God's Book of Nature; the application of natural knowledge to the improvement of trades was not ignoble because England's imperial destiny depended upon its commerce and its military technology. ${ }^{76}$

The civic legitimacy of the new experimental philosophy was to be secured by showing in just what ways it was not the old learning and its practitioners were not traditional scholars. Thus Thomas Sprat:

The common Accusations against Learning are such as these; That it inclines men to be unsetled, and contentious; That it takes up more of their time, than men of business ought to be bestow; That it makes them Romantic, and subject to frame more perfect images of things, than the things themselves will bear; That it renders them overweening, unchangeable, and obstinat; That thereby men become averse from a practical cours, and unable to bear the difficulties of action; That it emploies them about things, which are no where in use in the world; and, That it draws them to neglect and contemn their own present times, by doting on the past. But now I will maintain, that in every one of these dangers Experimental Knowledge is less to be suspected than any other; that in most of them (if not all) it is absolutely innocent; nay, That it contains the best remedies for the distempers which some other sorts of Learning are thought to bring with them. ${ }^{77}$

The old learning was by merit raised to its bad eminence. According to John Aubrey, the whole of learning in the sixteenth and early seventeenth centuries was "Pædentry, i.e. criticall learning"; scholarly style was "pedantique, stuff't with Latin, \& Greeke sentences, like their Clothes"; it "was but a sad, \& slavish labour". ${ }^{78}$ Joseph Glanvill was unrestrained in diagnosing the old scholarship as pedantry: it was a "disputing physiology"; it taught men to "cant endlessly", to "dress up Ignorance in words of bulk and sound, which shall stop the mouth of enquiry, and make learned fools seem Oracles among the populace". So long as school-philosophy defined what it was to be learned, how could scholarship attract "Men of generous Spirit", how could learning seem "otherwise then contemptible, in the esteem of the more enfranchised and sprightly tempers"? Its dissolution by the new experimental practice was nothing less than "striking at the root of Pedantry". ${ }^{79}$

The traditional scholar was solitary, morose, melancholic. So far as 
gentlemanly society was concerned, "If they can bring such Inquirers under the scornfull Titles of Philosophers, or Schollars, or Virtuosi, it is enough: They presently conclude them, to be men of another World, onely fit companions for the shadow, and their own melancholy whimsies". The experimental philosopher was, however, of a quite different humour: sociable, pliant and polite. Indeed, these virtues were the condition for the production of reliable knowledge: "The Natural Philosopher is to begin, where the Moral ends. It is requisite, that he who goes about such an undertaking, should first know himself, should be well-practis'd in all the modest, humble, friendly Vertues: should be willing to be taught, and to give way to the Judgement of others." have argued elsewhere that a gentlemanly code regulating manners in dispute was locally effective within the community of those willing to subscribe to the rules of the new philosophical game. The peaceable commonwealth of experimental natural philosophers liberally helped itself to codes of conduct pre-existing in genteel society. ${ }^{81}$ The school-philosopher was, from this perspective, rightly despised as opinionated, magisterial and litigious. His dogmatism was a token of his baseness and unfitness for genteel society:

To be confident in Opinions is ill manners and immodesty. ... It betrayes a poverty and narrowness of spirit, in the Dogmatical assertors. There are a set of Pedants that are born to slavery.

And while experimentalists formed a community of free agents, submitting to no man's authority, they used that integrity and freedom to secure cultural and civic order:

[T] he more generous spirit preserves the liberty of his judgement, and will not pen it up in an Opinionative Dungeon. ... When as the Pedant can hear nothing but in favour of the conceits he is amorous of; and cannot see, but out of the grates of his prison; the determinations of the Nobler mind, are but temporary, and he holds them, but till better evidence repeal his former apprehensions. ${ }^{82}$

Good manners made good knowledge.

The experimental community was a "Society of persons of Quality and Honour", incorporated to serve the civic interest. Its celebrants trusted "that the eminence of your condition, and the gallantry of your Principles, which are worthy those that own them, will invite Gentlemen to the useful and enobling study of Nature, and make Philosophy fashionable". Glanvill announced that the Royal Society had already "redeemed the credit of Philosophy" and made it suitable for gentlemanly participation: "I hope to see it accounted a piece of none of the meanest breeding to be acquainted with the Laws of Nature and the Universe. And doubtless there is nothing wherein men of birth and fortune 
would better consult their treble interest of PLEASURE, ESTATE, AND HONOUR, then by such generous researches." 83

Moreover, publicists of the new experimental philosophy had secured a precious rhetorical prize - the person of the Honourable Robert Boyle. For all that has been written in recent years about Boyle, his emblematic significance for the legitimacy of the experimental enterprise has yet fully to be appreciated. Boyle was at once the most noble and the most intellectually central of the early Royal Society's active fellowship. The son of the Earl of Cork, the proprietor of a major fortune, and a man of widely known personal probity and Christian piety, Boyle was not just a learned man but a man of learning, identified with the pursuit and dissemination of knowledge. His participation was seen as giving the experimental community its particular legitimacy as resolution of the endemic problems attending the relations between the polite and the learned worlds. From early in his life Boyle wrestled with the great topics in that problematic. Was the happy and virtuous life to be lived in society or in seclusion? How could one, while engaged in the search for truth, acquit one's responsibility to one's fellow men? What form of culture was it which allowed one to pursue truth virtuously and which promoted virtue in its practitioners? In a series of publications from the early 1660 s Boyle announced that the experimental philosophy was just that practice: it was a form of learning which was not only suitable for the gentleman, but which was necessary for the gentleman to fulfil his divinely ordained role in civil society. ${ }^{84}$ The "Christian virtuoso" was more rather than less authentically a gentleman for his philosophical pursuits. It was experimental natural philosophy that elevated him both in its objects and in its social practice; it was this study of nature that made him magnanimous, disciplined, modest, generous, peaceable, and civically useful. It was Christianity, and whatever cultural forms most conduced to Christian belief, that sustained the originally secular Renaissance commitment to an active life for a gentleman. The new science buttressed Christianity; and the new science was for that reason a handmaiden to the civic life. ${ }^{85}$

In these ways, Boyle was offered, and offered himself, as a pattern of the English Christian gentleman that was being canvassed by such religiously orientated English courtesy texts as Brathwait's The English gentleman (1630), Richard Allestree's Gentleman's calling (1660), Clement Ellis's The gentile sinner (1660); William Ramesey's The gentlemans companion (1669); and such moral tracts as Sir Thomas Browne's Religio medici (1643) and Christian morals (comp. 1650), and Sir George Mackenzie's Religio stoici (1665), Moral essay (1665), Moral paradox (1667) and Moral gallantry (1667). ${ }^{86}$ While still a young man Boyle was pervasively pointed to as the exemplar of what it was to be a Christian gentleman and a Christian philosopher. Glanvill suggested that in other ages he would have been regarded as a "deified Mortal". His writings 
combined "the gentilest smoothness, the most generous knowledge, and the sweetest Modesty" with "the most devout, affectionate Sense of God and of Religion". ${ }^{87}$ At his funeral his life was painted as the "Character of a Christian Philosopher". He was "the purest, the wisest, and the noblest" of men. His life was "a pattern of living"; "nature seemed entirely sanctified in him"; he never "offended any one person, in his whole life, by any part of his deportment"; he "was exactly civil, rather to ceremony"; he "had nothing of the moroseness, to which philosophers think they have some right" ${ }^{88}$ In specific terms, the Honourable Robert Boyle was the instantiation of the Christian experimental natural philosopher; in general terms, his life and work were mobilized as a concrete representation of the new gentleman-scholar.

\section{PEDANTRY AND THE IDEA OF THE GENTLEMAN, 1660-1760}

The early Royal Society sought nothing less than the effective re-specification of the ideas of knowledge and gentility. Repertoires descriptively and normatively opposing the idea of the gentleman and the idea of the scholar were to be dissociated and recombined in a new culture and a new role of the gentlemanscholar. Local claims for the potency of that re-specification were vehement. According to publicists like Sprat and Glanvill, the mere existence of the Royal Society as a thriving community of gentlemanly scholars proved the success of the re-specification. Henry Oldenburg used his network of correspondents to circulate the pattern throughout the world of letters. Both the polite and the learned worlds were said to be flocking to the new standard. In the late 1660s a Christian courtesy writer argued against the deep study of logic and rhetoric for the gentleman - they resulted in "Contention and Ostentation" - but much preferred "Experimental Philosophy ..., especially the Spagyrical, and Cartesian; Experience being that chief thing indeed, that perfects our Studies" ${ }^{89}$ Gilbert Burnet's Thoughts on education, written for a Scots aristocrat, recommended "the chieffe experiments that are of late made; and this is the best apparatus for philosophy". If the young man "be of a composed mind and moderate spirit", he may also "look discreetly into chymistry", as this "may oblige him to love home, and seek a retired life"..$^{90}$ In the late seventeenth century "Battle of the Books" between "ancients" and "moderns", the great defender of modern learning William Wotton announced the end of pedantry and the dissolution of the distinction between scholars and gentlemen. The basis of the ancients' charge "of the great Decay of Modern Learning is Pedantry", but this was a sign that their proper target was not learning "as it now stands, but as it was Fifty or Sixty Years ago". The difference was made by "the new Philosophy" which had, Wotton claimed, succeeded in introducing a great "Correspondence between Men of Learning 
and Men of Business". That "Pedantry which was formerly almost universal, is now in a great Measure dis-used". ${ }^{91}$

The British natural philosophical community and its publicists developed the celebration of Boylean nobility and piety into a centre-piece of natural theological rhetoric and cultural legitimation. Gilbert Burnet's eulogy to Boyle as gentleman-scholar remained in print and influential well into the nineteenth century. In America Cotton Mather's Christian philosopher (1721) dispersed the Boylean template to a new world. Among courtesy texts The gentlemans companion recommended a few well-chosen books for the Christian gentleman's library, notably including "The Honourable Mr. Boyl his Stile of the Scripture", and "the Great Boyl his Experimental Natural Philosophy, and the rest of his Works".92 And Daniel Defoe's The compleat English gentleman strongly recommended "experimentall as well as naturall phylosophy" as "the most agreeable as well as profitable study in the world". He claimed that rural gentlemen-virtuosi were becoming among the most admired men in their counties. As an apocryphal minister said of the local virtuoso, "I never met with so much wit ... and so much polite learning in any gentleman of his age in my life. We were talking phylosophy the other day with him; why he has treasur'd up a mass of experiments of the nicest nature that I ever met with; he has the Phylosophic Transaccions allmost by heart ...." And, while Defoe condemned the continuing "voluntary and affected stupidity and ignorance" of the English gentry, he pointed to an influential pattern of nobility combined with disinterested dedication to science: "the great and truly honorable $\mathrm{Mr}$. Boyl, who was not a gentleman onely, not a man of birth and blood as to antiquity [sic] onely, but in degree also, being of noble blood and one of the families that has the most enobl'd branches of any in England and Ireland." 93 A late eighteenth century editor reminded readers that Boyle "was himself 'The Christian Virtuoso' which he has described". ${ }^{44}$ And in 1796 the editor of Izaak Walton's Lives wrote of Boyle: "To the accomplishments of a scholar and a gentleman, he added the most exalted piety, the purest sanctity of manners." 95

Despite the grand ambitions of the early Royal Society and this fragmentary evidence apparently pointing towards success, it would be pointless to suggest that the experimental community - however loosely defined - achieved the wholesale overthrow of traditional attitudes to the gentleman and the scholar, or even to what counted as legitimate and valuable knowledge. Of course, no such revolution occurred. Nonetheless, patterns of British attitudes towards knowledge and gentility in the 'long eighteenth century' were enormously consequential, bearing upon the legitimacy of the new knowledge and the institutionalization of the new knower's role. These matters need to be considered mainly from the point of view of gentlemanly polite society, for it was overwhelmingly that society through the eighteenth century which had the 
gift of support and legitimacy in its hands. Although the social distribution of literate culture underwent substantial change from the Restoration to the French Revolution, within polite society ideas of gentility in general and attitudes towards the relationship between the gentleman and the scholar in particular changed with glacial slowness. ${ }^{96}$ And, as I shall note later, when marked changes in attitudes did develop in the latter part of the eighteenth century, they did so outwith the boundaries of traditional gentlemanly society. Meanwhile, within polite society traditional attributions about learning and men of learning tended to persist. The very Defoe text which castigated the gentry for their sloth and ignorance and which advertised Boyle as a paragon of learned noble virtue also made clear the recommended limits of genteel learning: "I distinguish between a learned man and a man of learning as I distinguish between a schollar and a gentleman." 97

In fact, late seventeenth and eighteenth century social and cultural commentary, tracts on education, and practical courtesy literature continued to characterize pedantry as a major disqualification for genteel society. Scholarly pedantry was pervasively treated, and few texts dealing with the subject regarded pedantry as a thing of the past. Negotiating one's way between wisdom and prudence, on the one side, and pedantry, on the other, was an immensely important practical problem in establishing membership and standing within the society of gentlemen. Lingard's Advice to a young gentleman warned the new graduate: "When you come into Company, be not forward to show your Proficiency, nor impose your Academical Discourses, nor glitter affectedly in Terms of Art"; The rules of civility sternly cautioned against speaking in company "in a language that the rest do not understand"; Rules of good deportment abominated the "Spirit of Contradiction" and counselled that "Obstinacy is contrary to the Laws of Civility": "It is not civil in all Occasions to use Syllogisms, and to deliver our thoughts in Mood and Figure; such Philosophical Cant suits the School, yet not common Converse."98 Samuel Butler characterized the pedant as the violator of decorum. He does not converse but rather lectures: "He speaks in a different Dialect from other Men, and much affects forced Expressions, forgetting that hard Words, as well as evil ones, corrupt good Manners." 99 The scholar's learning was not genuine knowledge at all:

... The artificialst Fooles

Have not been changd i' th' Cradle but the Schooles:

Where Error, Pædentry, and Affectation

Run them, behind Hand, with their Education. ${ }^{100}$

In 1673 Obadiah Walker, Master of University College, Oxford, published an influential tract on education for young gentlemen which pointed to pedantry as a continuing problem for polite society. Well-born youth should 
acquire a "sufficient perfection" in their studies, "not so much as is required for a Professor, but so much, as is necessary or requisite for a Gentleman". "Do not", Walker warned, "in ordinary company treat of matters too subtil and curious, nor too vile and mean":

Pedantry is a vice in all Professions, it self no Profession. For a SchoolMaster is not therefore a Pedant; but he onely who importunately, impertinently, and with great formality, shews his learning in scraps of Latin and Greek; or troubles himself with knowledge of little use or value; or values himself above his deserts, because of something he knows (as he conceives) more then ordinary; or despiseth others not skilled in his impertinences; or censures all Authors and persons confidently without reason. And whoever doeth thus, be he Divine, Lawyer, Statesman, Doctor, or Professor, he is a Pedant. ${ }^{101}$

Even writers, like William Temple, concerned vigorously to defend the worth of traditional forms of scholarship acknowledged that genteel scorn of learning had been largely brought about by the deplorable behaviour of many scholars:

The last maim given to learning, has been by the scorn of pedantry, which the shallow, the superficial, and the sufficient [over-confident] among scholars first drew upon themselves, and very justly, by pretending to more than they had ..., by broaching it in all places, at all times, upon all occasions, and by living so much among themselves, or in their closets and cells, as to make them unfit for all other business, and ridiculous in all other conversations. ${ }^{102}$

The Earl of Shaftesbury developed the critique of pedantry and systematic learning into one of the foundations of his good-humoured and commonsensical civil polity. The pedant's canting and hectoring causes "a breach of the harmony of public conversation"; it "puts others into silence, and robs them of their privilege of turn". All knowledge worthy of the name is selfknowledge, to be gained by "soliloquy" and the interrogation of self, and not by turning a philosophic gaze onto the world of nature and its alleged underlying processes. That way, the objects of knowledge stand in a direct relationship to the civic uses of knowledge: "A good poet and an honest historian may afford learning enough for a gentleman. ... The truth is, as notions now stand in the world with respect to morals, honesty is like to gain little by philosophy, or deep speculations of any kind. In the main, 'tis best to stick to common sense and go no farther. ... The mere amusements of gentlemen are found more improving than the profound researches of pedants." 103

Such fashionable eighteenth century periodicals as The tatler and The 
spectator dilated upon scholarly incivility and pedantry, nowhere betraying any sense that pedantry had been either eliminated or eroded by the new philosophy. Joseph Addison reckoned that "A Man who has been brought up among Books, and is able to talk of nothing else, is a very indifferent Companion, and what we call a Pedant", generalizing the term to anyone who cannot think "out of his Profession, and particular way of Life". ${ }^{104}$ Such a man could give no pleasure in company. Richard Steele pointed to scholarly lecturing, carping and quibbling as the bane of civil conversation. Scholars insisted upon teaching and instructing others, while the good order of gentlemanly conversation depended utterly upon participants' presumed equality: "it is the greatest and justest skill in a man of superior understanding, to know how to be on a level with his companions." The greatest enemies of "good company", and those who most violated "the laws of equality (which is the life of it), are the clown, the wit, and the pedant". ${ }^{105}$ To Dr Johnson pedantry was "the unseasonable ostentation of learning". The solitary meditation of scholars was responsible for their social solecisms and clumsiness: "To trifle agreeably, is a secret which schools cannot impart; that gay negligence and vivacious levity, which charm down resistance wherever they appear, are never attainable by him who having spent his first years among the dust of libraries, enters late into the gay world with an unpliant attention and established habits." In Johnson's view, a necessary condition for the pursuit of knowledge was "retirement", and retired settings in turn bred up scholars unsuited for polite society. 106

Chesterfield's Letters to his son represent eighteenth century English polite society's view of learning and the learned at the most practical level. By all means, "hoard up, while you can, a great stock of knowledge" and do it in your youth so that you can in later life draw upon it "to maintain you". However, do not equate valuable knowledge with that found in books or academic researches: "Let the great book of the world be your serious study." When you have laid up your stock of knowledge, do not display it promiscuously or lecture others: "From the moment you are dressed and go out, pocket all your knowledge with your watch, and never pull it out in company unless desired. ... Company is a republic too jealous of its liberties to suffer a dictator even for a quarter of an hour ...." The society of men of learning is not what is meant by "good company"; "they cannot have the easy manners and tournure of the world, as they do not live in it". The pedant does not communicate his knowledge, "but he inflicts it upon you"; "such manners as these ... shock and revolt". Scholars' abstract and generally useless learning was never to be identified with genuine knowledgeability. Gentlemanly society required prudence and experience, not bookishness or philosophy. Indeed, the civic irrelevance of scholars' knowledge derived from the solitary circumstances in which it was produced. This was why genteel society considered that 
it might take scholars' boorishness and incivility as a reliable gauge of their uselessness. The man of learning "has no knowledge of the world, no manners, no address. ... His theories are good, but unfortunately are all impracticable. Why? Because he has only read and not conversed. ... His actions are all ungraceful; so that, with all his merit and knowledge, I would rather converse six hours with the most frivolous tittle-tattle woman, who knew something of the world, than with him."107

\section{PEDANTRY AND THE NEW SCIENCE}

It might be supposed that the gentlemanly critique of pedantry distinguished between traditional scholarly enterprises and the new science. After all, Bacon and the early Royal Society had sought to eliminate the old pedantry and to reform learning so as to make it appropriate for gentlemen. Yet there is little indication in the literature produced by and for polite society that the new science was in any way exempted from the pervasive condemnation of pedantry and the scholar's way of life. Of all writers on the practical education of gentlemen in the late seventeenth century John Locke had the most reason to recommend the new philosophy, both natural and moral. Fellow of the Royal Society, friend and collaborator of Boyle, Locke was intimately familiar with the experimental programme and its civic justification. Yet there was little difference between Locke and the courtesy writers when it came to the diagnosis of scholarly distempers. "Prudence and good Breeding" are necessary; most of what passes as "Learning" is not. Only "a very foolish Fellow" would not "value a virtuous or a wise Man infinitely before a great Scholar". Learning can as easily mar as improve a character. "Learning must be had, but in the second Place, as subservient only to greater Qualities." Locke specifically warned well-born youth against acquiring "the just Furniture of a Pedant ... than which there is nothing less becoming a Gentleman". ${ }^{108}$ In fact, there were reasons for giving the natural sciences some place in the gentleman's education - insofar as they could offer solidity and certainty. Yet, no matter how favourably disposed he was to Boylean corpuscularianism and probabilism, Locke did not see that any system of natural philosophy could offer uncontrovertibility: "Tho' the World be full of Systems of [Natural Philosophy], yet I cannot say, I know any one which can be taught a young Man as a Science wherein he may be sure to find Truth and Certainty, which is what all Sciences give an Expectation of." There was no actual harm in acquiring a passing familiarity with the systems of Descartes, Boyle and Newton; indeed "There are very many Things in [them] that are convenient and necessary to be known to a Gentleman". But neither natural philosophy nor any other reformed study of nature was to have more than a peripheral place in the fashioning of a gentleman. The success of Locke's programme can be gauged 
from the mature views of the young man he was then tutoring, the future third Earl of Shaftesbury. ${ }^{109}$

The courtesy literature and related tracts clearly failed to exempt the new science from its continuing critique of pedantry and the learned. Moreover, very many polite cultural productions specifically identified Royal Society learning as, at best, just another sort of learned nonsense and, at worst, as a particularly virulent and offensive type of pedantry, more unsuited to gentlemanly participation than traditional practices. It is not my purpose here to review the literature on Restoration and Augustan scientific 'satire' so well treated by inter alia R. H. Syfret and Marjorie Hope Nicolson. ${ }^{110}$ Rather, I want briefly to show in what ways rejection of the new practice produced by and for genteel society mobilized repertoires contrasting the gentleman and the scholar which had been current at least since the sixteenth and early seventeenth century. In this connection, the identification of the new science as trivial, silly or just funny was arguably more devastating than its portrayal as dangerous. Defenders of the new learning acknowledged this fact: "Nothing wounds more effectually than a Jest; and when Men once become ridiculous, their Labours will be slighted, and they will find few Imitators." 111 Amused or exasperated condescension was the language traditionally used by polite society to reject learning and the learned; the language of threat and danger in relation to intellectual forms was more customarily employed within clerkly circles. The humanistic re-specification of knowledge and the knower instigated by Bacon and exemplified by the early Royal Society had not only failed to institutionalize the new role of the gentleman-scholar, it had failed to bring about a significant change in the repertoires which polite society used to keep learning and the learned at arm's length. What was said of the new learning and the new learned through the eighteenth century was mutatis mutandis much the same as had been said of trivial scholarship and "dizzard" scholars in the sixteenth century.

The themes are familiar. It was said, firstly, that the objects of the new practice were trivial or ignoble, unworthy of the attention of gentlemen, irrelevant to their concerns, and inappropriate to polite conversation; secondly, that the new knowledge was abstract and useless, making no contribution to the polity, and perpetrating fraud when useful outcomes were claimed for it; thirdly, that the new practice was in no way less disputatious or litigious than the old Scholasticism, and that the new practitioners were as given to pomposity, ostentation, canting, hectoring, and lecturing; and, finally, that the new knowledge was no better, or even worse, than the old in its effects on practitioners' manners, civility and fitness for polite society.

Samuel Butler's satires were among the earliest to attach the charge of pedantic triviality to the Royal Society's empirical and experimental practice. From 1663 Hudibras and other mock-heroic poems specifically targeted the 
new natural philosophy as one of the more prominent contemporary pompous frauds and "abuses of learning". Butler's Padants tendered a stock early Restoration joke about the vacuousness of Boylean science:

A Pædagogue, that mounted in his Schoole

Is but a Kinde of Master of Misrule,

Is Puft up with his own conceipt, and Swels

With Pride and vanity and Nothing else,

Like Bladders in the Late Pneumatique Engine,

Blown up with nothing but their owne Extension. ${ }^{112}$

The elephant in the moon identified the triviality of the objects of the Royal Society's inquiry (flies, mice), the grandiose, pompous and deluded claims made for them (elephants), and the dishonourable conduct of virtuosi in attempting to suppress the truth. ${ }^{113}$ Butler's Satyr upon the Royal Society was one of several Restoration japes which showed how little the claimed utility of the new science was credited:

These were their learned Speculations

And all their constant Occupations;

To measure Wind, and weigh the Air, And turn a Circle to a Square .... ${ }^{114}$

Shadwell's The virtuoso mercilessly lampooned the ignobility of the phenomena so obsessing Sir Nicholas Gimcrack. The natural theological rhetoric which saw divine wisdom in the architecture of a louse and heard sermons in gall-stones clearly won little applause in fashionable circles. In his nieces' opinion Gimcrack was a bathetic fool: "A sot that has spent two thousand pounds in microscopes to find out the nature of eels in vinegar, mites in cheese, and the blue of plums which he has subtly found to be living creatures. One who has broken his brains about the nature of maggots, who has studied these twenty years to find out the several sorts of spiders, and never cares for understanding mankind." The foppish pedant Sir Formal Trifle agreed that "no man upon the face of the earth is so well seen in the nature of ants, flies, humble-bees, earwigs, millipedes, hog's lice, maggots, mites in a cheese, tadpoles, worms, newts, spiders, and all the noble products of the sun by equivocal generation."115

The satirist William King ridiculed the Royal Society's virtuosi and philosophers for mucking around with "the very dregs of Nature". Boyle's swilling about in human urine and faeces to extract the phosphorus and Leeuwenhoek's investigations into the globular structure of mouth-slime elicited a polite retch-reflex as well as a smirk. The air-pump was never funnier:

I had several discourses with Mr. Muddifond, about 'an old cat and a young kitling in an air pump, and how the cat died after 16 pumps, but the 
kitling survived 500 pumps.' Upon which, he fell into a learned discourse, of the lives of cats; and at last agreed upon this distinction, That it ought not to be said that cats, but that kitlings, have nine lives. ${ }^{116}$

Royal Society apologists from John Wilkins to Robert Hooke and Robert Boyle urged the nobility as well as the sublimity of inquiry into nature's smallest and most wretched creatures: "The creation of a glorious angel did not cost [God] more than that of a despicable fly." 117 Polite society remained largely unpersuaded that the flies and lice were anything but despicable. Nice inquiries just weren't nice.

The tatler judged the "immensity" of nature a more noble philosophical object than its "minuteness". Just because "the world abounds in the noblest fields of speculation", it was the "mark of a little genius to be wholly conversant among, insects, reptiles, animalcules, and those trifling rarities that furnish out the apartment of a virtuoso". Men whose "heads are so oddly turned this way" tend to be "utter strangers to the common occurrences of life":

I would not have a scholar, wholly unacquainted with these secrets and curiosities of nature; but certainly the mind of man, that is capable of so much higher contemplations, should not be altogether fixed upon such mean and disproportioned objects. Observations of this kind are apt to alienate us too much from the knowledge of the world, and to make us serious upon trifles. ... In short, studies of this nature should be the diversions, relaxations, and amusements; not the care, business, and concern of life. ${ }^{118}$

Natural philosophy in its modern virtuosic practice did not "so much tend to open and enlarge the mind" as to "fix it upon trifles": "This in England is in a great measure owing to the worthy elections that are so frequently made in our Royal Society. They seem to be in a confederacy against men of polite genius ...." 119 Feminist satirists endorsed their polite brothers' strictures. An essay in defense of the female sex characterized the "virtuoso" as one who had "abandoned the Acquaintance and Society of Man for that of Insects, Worms, Grubbs, Maggots, [and] Fleas". 120

Shaftesbury systematized polite opinion on the matter. There was nothing about learning as such that was at all culpable for gentlemanly pursuit:

But when we push this virtuoso character a little further and lead our polished gentleman into more nice researches, when from the view of mankind and their affairs, our speculative genius and minute examiner of Nature's works proceeds with equal or perhaps superior zeal in the contemplation of the insect life, the conveniencies, habitations, and 
economy of a race of shell-fish; when he has erected a cabinet in due form, and made it the real pattern of his mind, replete with the same trash and trumpery of correspondent empty notions and chimerical conceits, he then indeed becomes the subject of sufficient raillery, and is made the jest of common conversations. ${ }^{121}$

Systematic learning or philosophy had nothing to teach the gentleman, no lessons for civil society. As Joseph Levine has rightly noted, many late seventeenth and early eighteenth century critics "found the whole business of examining nature irrelevant, however it was conducted". ${ }^{122}$ There was little if any relevant contrast drawn by polite critics between an antiquarian pedant and a Newton. What was important in civil society was knowing what the right thing was and then doing it. What had any brand of "philosophy" to contribute to that end? The proper study of mankind was man. If scholars and divines wanted the moral order underwritten indirectly, for example, via the study of God's design manifest in nature, gentlemanly society preferred to take its ethics neat. Whether the atomists or the plenists were in the right simply did not matter to practical life: "My mind, I am satisfied, will proceed either way alike, for it is concerned on neither side. 'Philosopher, let me hear concerning what is of some moment to me. Let me hear concerning life what the right notion is, and what I am to stand to upon occasion ...." "123

Syfret followed Houghton in discerning in Restoration criticisms of the new science a significant distinction between "Baconians", pursuing natural knowledge as it tended towards use, and "the virtuosi", cultivating knowledge for its own sake. ${ }^{124}$ Such a distinction may indeed capture something about practitioners' varying goals, but little was made of it in contemporary censure and satire. In the view of polite critics, it amounted to a distinction between those who never thought to turn knowledge to civic account and those who fraudulently claimed to have done so. The utilitarian claims of the "Baconians" were not credited; the aims of virtuosic curiosi were ridiculed in their own terms; and the practice of both was roughly equated with the civically useless sequestered and abstracted modes which polite society since the Renaissance had overwhelmingly rejected. Shadwell's Gimcrack said that he was concerned with the "speculative part" of knowledge: "I care not for the practic. I seldom being anything to use, 'tis not my way." 125 And when Gimcrack's house was besieged by proto-Luddite ribbon-weavers, convinced that he had invented an engine-loom putting them all out of work, the virtuoso protested his innocence: "I never invented anything of use in my life"; "We virtuosos never find out anything of use, 'tis not our way."126

William Temple spoke not just for "ancient" scholars but for the generality of polite society when he asked: "What has been produced for the use, benefit, or pleasure of mankind, by all the airy speculations of those who have passed 
for the great advancers of knowledge and learning these last fifty years ... [?]"127 Temple's client Jonathan Swift captured the technological ambition of the Royal Society in his "Grand Academy of Projectors" in Lagado, "where the professors contrive new rules and methods of agriculture and building", and where, in consequence, "the whole country lies miserably waste, the houses in ruins and the people without food or clothes". ${ }^{128}$ The tatler's Gimcrack, believing on philosophical grounds that "there was no such thing in nature as a weed", sacked his gardener, reducing his previously well-ordered grounds to a tangle of weeds. He ruined his fortune, spending lavishly on cabinets stuffed with "rat's testicles, and Whales pizzle", and dying destitute, if not precisely intestate. ${ }^{129}$ William Temple and William King both found the Royal Society's utilitarian pretensions so obviously bogus that they had only to be enumerated for their fraudulence to be evident: rejuvenation by transfusion, a universal language, double-bottomed ships, the art of flying. ${ }^{130}$

If the perpetration of fraud was one specific distemper of the new learning, its unmannerly ostentation was a more general vice disqualifying practitioners from polite society. If, as Dr Johnson said, pedantry was the display of knowledge out of place, then the new learning was no less culpable than the old. Samuel Butler saw little distinction between the naturalist-virtuoso and the antiquary-grammarian in this respect: "[The virtuoso] is a Haberdasher of small Arts and Sciences. ... He differs from a Pedant, as Things do from Words; for he uses the same Affectation in his Operations and Experiments, as the other does in Language." 131 The tatler cautioned that "It is the duty of all who make philosophy the entertainment of their lives, to turn their thoughts to practical schemes for the good of society, and not pass away their time in fruitless searches, which tend rather to the ostentation of knowledge than the service of life". ${ }^{132}$ Temple recommended ancient learning over modern because the former was decorously modest while "ours leads us to presumption, and vain ostentation of the little we have learned". ${ }^{133}$ King identified ostentation rather than utility or curiosity as the motive force of the new philosophical cant. "Gentleman" asks "Virtuoso" about the use of narratives about fossil bones, and Virtuoso replies:

You mistake the Design: it was never intended to advance Natural knowledge; for who is the wiser for knowing that the bones of a dead fish have been dug up, or where? No, the true use of the story is to amuse the ignorant; for, if they talk of things that are out of the way, we presently make an harangue about 'the Mandibulum of a Pastinaca Marina found fossile' in 'Maryland;' and then they 'are silenced at an instant.' 134

Pomposity is ostentation without a hint of a smile, and the piously po-faced earnestness of some notable expressions of the new natural philosophy attracted the ridicule of those polite critics who found it all too tedious. The 
virtuoso cruelly spoofed Boyle's profession that he had "read a Geneva Bible" by the "light of a rotten leg of pork". (Shadwell exaggerated quite unfairly: it was veal and the text was the Philosophical transactions. ${ }^{135}$ The bonhommic wit Sir Samuel Hearty had to apologize for giving offence to Gimcrack: "you know I am an airy, brisk, merry fellow, and facetious, and his grave philosophical humour did not agree with mine. Besides, he does not value wit at all ... he's an enemy to wit as all virtuosos are." 136 Samuel Butler's satire of Boyle's Occasional reflections picked out the attempted ennobling of the louse as pompous twaddle. Jonathan Swift followed with a spoof meditation on divine design as manifested in a broom-stick which was too deft to raise a laugh from Lady Berkeley, and there is even evidence that the libidinous Rochester circle had fun at pious Boyle's expense. ${ }^{137}$ Shaftesbury urged "raillery" and good humour as a test of veracity, "For without wit and humour, reason can hardly have its proof":

Grimace and tone are mighty helps to imposture. And many a formal piece of sophistry holds proof under a severe brow, which would not pass under an easy one. 'Twas the saying of an ancient sage 'that humour was the only test of gravity; and gravity of humour. For a subject which would not bear raillery was suspicious; and a jest which would not bear a serious examination was certainly false wit.' 138

By this criterion, the pomposity of the new science gave adequate grounds for polite society to suspect its truthfulness.

Moreover, it was said that the practitioners of the new learning were just as quarrelsome and disputatious as their predecessors. Butler's character of "A philosopher" tarred the new natural philosophers with the same brush they had used for the Schoolmen:

When his Profession was in Credit in the World, and Money was to be gotten by it, it divided itself into Multitudes of Sects, that maintained themselves and their Opinions by fierce and hot Contests with one Another; but since the Trade decayed, and would not turn to Account, they all fell of themselves, and now the World is so unconcerned in their Controversies, that three Reformado Sects joined in one, like EpicuroGassendo-Charletoniana, will not serve to make one Pedant. ${ }^{139}$

Swift's Laputans were not only "Very bad reasoners" but "vehemently given to opposition, unless when they happen to be of the right opinion, which is seldom the case": "I have indeed observed the same disposition among most of the mathematicians I have known in Europe." ${ }^{140}$ Genteel society in the late seventeenth and early eighteenth century was well apprised of the acrimonious disputes involving such major modern English natural philosophers, naturalists and mathematicians as Robert Boyle, John Wallis, Thomas Hobbes, 
Martin Lister, Robert Hooke, John Flamsteed, and, spectacularly, Isaac Newton. ${ }^{141}$ Irenic professions by leading figures of the early Royal Society were, for this and other reasons, not widely credited. The period from $c .1695$ to $c .1710$ was marked by particularly serious personal bickering in the Royal Society. Accusations of disingenuousness were broadcast; challenges were made; duels were threatened. For polite society the naturalist and antiquarian John Woodward became the pattern of a litigious and quarrelsome philosopher as well as a pedant. ${ }^{142}$

What gentleman would want to spend an evening in such company? Polite opinion was strongly of the view that practitioners of the new science were every bit as boorishly ill-mannered as the general run of scholars had always been. Again, in fashionable condemnation of the virtuoso and the naturalist, Dr Woodward came to stand for the type. Courtesy to guests was strongly enjoined in gentlemanly society, and accounts of the doctor's epic rudeness to curious visitors became collector's items of their kind. A German visitor was intentionally kept waiting for hours in the parlour: "This is the discourteous little ceremony that the affected and pedantic mountebank makes a habit of going through with all strangers who wait on him." The English naturalist Samuel Dale was smartly reprimanded by Woodward for speaking to a friend while their host was holding forth on a fossil: "“it was not manners to speak while another was speaking.' [Dale] thought he had never met such 'an ungenteel Banquet after a seemingly courteous invitation to a Rara show as at that Gentleman's Lodgings'." 143 Swift squelched the Laputan philosophers for their total lack of effortless grace or decorum: "in the common actions and behaviour of life I have not seen a more clumsy, awkward, and unhandy people." 144

An early eighteenth century courtesy text specifically identified the new natural philosophy as just another form of pedantry:

I would not have you upon all Occasions discourse in Syllogism, nor deliver your thoughts in Mood and Figure: such Philosophical Cant suits better with a Pedant, than a Gentleman; and may pass in the School, but not in the Parlour. Neither press upon Company a Vacuum, nor Mr. Boyle's Pondus Atmosphara, a civil conversation may be managed handsomly in either Hypothesis; and I conceive Discourse prospered no less in the Days of good old Materia Prima, than in the Reign of des Cartes's Third Element. ${ }^{145}$

Jolly gentlemen need not trouble their heads.

Dr Johnson's Rambler related a story about the social solecisms of a scientific scholar bred up in solitude and quite unable to make agreeable conversation in polite company. He had nothing suitable to say to the ladies, and found himself standing apart. Approached by a clergyman who asked the 
scholar "some questions about the present state of natural knowledge" and who affected interest in "the Newtonian philosophy", the scholar was drawn into pedantic babble grossly violating "the laws of conversation". The bored company turned its chatter to "the uselessness of universities, the folly of book-learning, and the awkwardness of scholars", and the philosopher made haste to leave, though not before spilling his tea, staining a lady's petticoat and scalding the lap-dog. ${ }^{146}$ If, as gentlemanly circles had agreed since the Renaissance, the test of proper knowledge was its ability to sustain and contribute to civil society, then incivility could be taken as an absolutely reliable sign that the new scientific knowledge was not a suitable object of polite participation or support. Bad manners meant bad knowledge.

\section{CONCLUSION}

The attempted re-specification of conceptions of learning and the learned by practitioners of the new science was a substantial failure. The new culture did not precipitate a new role of gentleman-scholar nor was polite society ever persuaded that a reformed systematic natural knowledge was a necessary gentlemanly accomplishment. Of course, during the eighteenth century certain forms of knowledge were persistently, and at times effectively, recommended to gentle society, and these notably included antiquarianism, civil and natural history, and even mathematics. ${ }^{147}$ Yet, while conceptions of appropriate knowledge changed, English polite culture continued to be marked by practical opposition between the ideal of the gentleman and the imputed characteristics of the scholar. Knowledge might be useful to a gentleman, but those whose role and identity were constituted by the serious pursuit of that knowledge were still regarded as having characteristics that spoiled their identity as competent members of gentle society. For the English upper-classes (not quite the same thing as the body of gentlemen) the danger of learning was (and is) the risk of appearing "too clever by half", and thus, by conventionally understood innuendo, being neither the gentleman, the Englishman, nor the Christian. And nothing argued or achieved by the practitioners of the new science from the time of Bacon to the time of Newton made much difference to that assessment.

The seventeenth century failure of re-specification was consequential for the institutionalization of science in England. It meant that the ambitions of Bacon and the early Royal Society for the flow of the new learning through the channels of polite society were not significantly realized. Yet failure to legitimate the new practice through one set of institutions, roles and values did not mean that it could not be done through other vehicles. I offer some brief speculations about the identity of two such alternative frameworks available during the period from the seventeenth to the nineteenth century. 
Firstly, from the middle of the eighteenth century England developed venues and vehicles for the support of scientific culture which were outside of traditional polite society and which partly developed in explicit opposition to polite values. From early in the eighteenth century non-conformist circles, particularly in the Midlands and North, supported dissenting academies deeply committed to 'modern' education, including the natural sciences. Later in the century, provincial scientific societies emerged strongly associated with the mercantile and manufacturing classes. We now have a generation of research in the social history of science that establishes significant links between approval of and participation in scientific culture and the emergence of the 'new men' of industrializing Britain. ${ }^{148}$ Many of these new men took seriously the scientific culture that the old élites had ridiculed and continued to reject. And texts such as Joseph Priestley's Essay on a course of education for civil and active life (1765) mapped a new pattern of gentility answering to the circumstances and goals of mercantile and manufacturing dissenters. Natural knowledge and mechanical arts were not, in this view, funny; they were fundamental to the formation of the new model gentleman and the new moral order. Elsewhere in industrializing circles, gentility was not co-opted but condemned, in favour of a seriously impolite utilitarian culture. Insofar as the classes which bore the new cultures prospered, thus far British society threw up significant alternative vehicles for the support and legitimation of science. By the 1830s, spokesmen of utilitarian culture articulated political demands for the professionalization of the scientific role and the state subvention of science - not because it fostered or was compatible with gentility but because it was materially useful to civil society. What was now asked for and achieved was state support, not for underwriting the role of the Christian philosopher and gentleman-scholar, but for that of the scientific expert. By the early twentieth century it was no longer required that scientific learning have any effect at all upon individual or communal virtue. ${ }^{149}$ The rump of polite society, whenever it formed an opinion of professional men of science, could think what it liked. And if the Brideshead jeunesse doré despised scientists as "northern chemists", nevertheless pater's taxes ultimately went to pay scientific salaries. ${ }^{150}$

The second set of vehicles for the support and legitimation of the new science is wholly traditional: the traditional scholar's role, the traditional institutions that sustained him, and traditional gentlemanly repertoires specifying the identity of the scholar and the value of his work. If the scholar was never to be a gentleman, still he might be tolerated, sustained, and, in certain important respects, valued. He might be a holy man or a solitary genius..$^{151}$ Precisely because he was not as other men, did not live with them, did not do as they did, and did not value what they valued, what he came to know might have a peculiar standing and worth. Indeed, the public display of the scholar's 
solitude and incivility could be taken as his intellectual bona fides. If Robert Boyle was offered up as the pattern of a gentleman-scholar, in late seventeenth and early eighteenth century English culture, Isaac Newton provided an extremely potent, and highly traditional, presentation of the man of science as otherworldly recluse. ${ }^{152}$

It was a presentation of scholarly self that was readily understood by polite society. It was attached to familiar institutions for its legitimacy and subvention. It drew upon familiar cultural repertoires. The value set upon the scholar's work was the price polite society paid for the goods he was considered in principle capable of producing: truth, the preservation and transmission of tradition, the legitimations needed by civil society, sacred, and, latterly, secular power. It was a presentation that identified the scholar, philosopher or intellectual as a special sort of person. Seen from the point of view of civil society, the scholar was at once commendable, contemptible and strange. Just as he might be condemned as a failed gentleman, he might also be valued as belonging to an order that played by different rules. Whoever he was, he was not one of us.

I know very little about the developing reference and resonance of the 'gentleman-scholar' usage as it emerged in the late eighteenth century. However, it would seem that the commonplace was rarely applied to practitioners of technically useful learning. Indeed, in Cardinal Newman's influential version "a gentleman's knowledge" was defined precisely by its nonutilitarian character, and, while the Edinburgh Whigs peddled useful knowledge to the lower and middling classes, Thomas Carlyle spoke for much gentlemanly society in associating mechanic knowledge with mechanic minds. ${ }^{153}$ One reference for the 'ge.ttleman-scholar' of the late eighteenth and early nineteenth century was, in all probability, someone legitimating claims to social standing by displaying morally textured antiquarian, civil or natural historical knowledge of locale - the "squarson"-naturalist or antiquary exemplified by White of Selborne. ${ }^{154}$ Perhaps the commonplace also developed through the nineteenth century in association with the ancient universities. If so, then it needs to be stressed that changes in access and reforms of the curriculum signified far-reaching shifts in institutional conceptions of both gentility and the scholarly life.

In modern educated middle-class company, both 'the scholar' and 'the gentleman' have for decades taken mandatory air-quotes. The gentleman's traditional civic exercise of moral authority and the scholar's disengaged moral proprietorship of systematic knowledge have both been supplanted by the same social person - the expert - leaving both the 'scholar' and the 'gentleman' as almost empty linguistic shells, roles well on their way to losing their institutions, their legitimacy, and, ultimately, their members. ${ }^{155}$ For this reason, I suspect that the commonplace has for some time been wide open to 
"A SCHOLAR AND A GENTLEMAN" • 315

ironic appropriation, increasingly so as one approaches time present. When I first started asking around about 'the scholar and the gentleman', one friend speculated that these days the formula was more commonly heard in lager advertisements and in the public bar as a sarcastic pleasantry than anywhere else or in any other sense. He was probably right. In The Scholar's Arms every man now goes through a door marked "Gents".

\section{ACKNOWLEDGEMENTS}

For constructive criticism of earlier versions of this paper I thank Peter Dear, Robert Iliffe, Philip Kitcher and David Philip Miller. Criticisms by Mario Biagioli and Mordechai Feingold were, unfortunately, received too late to be reflected in this paper.

\section{REFERENCES}

1. It is not clear from the context in The prelude whether Wordsworth pointed to "scholars" and "gentlemen" as two categories of individuals (as well he might have done in relation to contemporary Cambridge) or as two aspects of all the individuals concerned.

2. Additional late eighteenth century uses appear in an editorial comment in a 1796 edition of Izaak Walton's Lives (for which see p. 300 and ref. 95 below), and a review of Della Crusca's Poetry of the world in the 1788 volume of the Monthly review (as quoted in D. Roper, Reviewing before the Edinburgh, 1788-1802 (London, 1978), 77-78). The latter was kindly brought to my attention by Graham Richards.

3. See, e.g., John Henry Newman, Discourses on the scope and nature of university education ... (Dublin, 1852), 175-83. Newman here identified "a gentleman's knowledge" and the role of the university in supplying it, though I have not located his use of the relevant commonplace.

4. William Winstanley, The lives of the most famous English poets (London, 1687), 191. I thank Janet Browne for this reference. Antonia Fraser (Cromwell: The Lord Protector (New York, 1973), 659) quotes (without specifying a source) an almost identical form of words applied to the regicide clergyman Dr John Hewett in the Interregnum. I thank Philip Kitcher for bringing this reference to my attention.

5. Clearly, both the gentle and the learned worlds in the sixteenth and seventeenth centuries interacted internationally and many of their attributed characteristics were common to several national settings. My concern is with the situation in England. I use sources deriving from non-English contexts when such sources were important for Englishmen, whether in translation or not. Where there is evidence that English patterns importantly diverged from those elsewhere or that the English accounted themselves different in relevant respects from other nationalities, I draw attention to such evidence. I make no claims of the sort that the English were unique or that every culture was the same. Recent reaction to work of the same general form evidently dictates that what is obvious should now be explicit as well.

6. My use of this notion bears only partial resemblance to that of sociologists, e.g. M. Mulkay, Science and the sociology of knowledge (London, 1979), 71-72, 93-95, and G. N. Gilbert and M. Mulkay, Opening Pandora's box: A sociological analysis of scientists' discourse (Cambridge, 1984), 40, 56-62, and, following Mulkay, T. F. Gieryn, "Boundary-work

\section{Provided by the NASA Astrophysics Data System}


and the demarcation of science from non-science: Strains and interests in professional ideologies of scientists", American sociological review, xlviii (1983), 781-95, p. 783.

7. R. K. Merton, Science, technology and society in seventeenth-century England (New York, 1970; orig. publ. 1938); M. Weber, The Protestant ethic and the spirit of capitalism, trans. by Talcott Parsons (New York, 1958; orig. publ. 1904-5), esp. pp. 72, 181-2; also T. F. Gieryn, "Distancing science from religion in seventeenth-century England", Isis, 1xxix (1988), 582-93, pp. 583-7 (for a claim about Durkheimian inspiration). For culture as the stock of legitimations, see Mary Douglas in, for example, Cultural bias (London, 1978); How institutions think (Syracuse, N.Y., 1986), esp. pp. 45-47, 63, 112; Risk acceptability according to the social sciences (New York, 1986), esp. 67-68; and see an overview by several of her colleagues: M. Thompson, R. Ellis and A. Wildavsky, Cultural theory (Boulder, Col., 1990), esp. ch. 1.

8. Q. Skinner, "Some problems in the analysis of political thought and action", in J. Tully (ed.), Meaning and context: Quentin Skinner and his critics (Cambridge, 1988), 79-118, p. 117 (orig. publ. 1974); also idem, "Language and social change", in ibid., 119-32, pp. 131-2, and idem, "The idea of a cultural lexicon", Essays in criticism, xxix (1979), 205-24, p. 215. For an independent analysis of motives as both situated repertoires for describing and evaluating action and as determinants of action, see C. W. Mills, "Situated actions and vocabularies of motive", American sociological review, v (1940), 904-13.

9. For a survey of the courtesy genre, see, for example, J. E. Mason, Gentlefolk in the making: Studies in the history of English courtesy literature and related topics from 1531 to 1774 (New York, 1971; orig. publ. 1935), and, for the relationship between some of this literature and macro-social change, see N. Elias, The civilizing process, i: The history of manners: ii: Power \& civility, trans. by E. Jephcott (New York, 1982; orig. publ. 1939), esp. i, ch. 2.

10. The institucion of a gentleman (London, 1555), sig. A.iii.

11. Epictetus, Epictetus his manuell, trans. by J. Healey (London, 1616), 91 (quoted in W. L. Ustick, "Changing ideas of aristocratic character and conduct in seventeenth-century England", Modern philology, xxx (1933), 147-66, p. 149). Cf. Epictetus, The discourses and manual ..., ed. by P. E. Matheson (2 vols, Oxford, 1916), ii, 235. The place of neoStoicism in early modern English social thought needs fuller treatment, especially in relation to ethical theory and its practical use in justifying social roles; see, e.g., G. Oestreich, Neostoicism and the early modern state, ed. by B. Oestreich and H. G. Koenigsberger, trans. by D. McLintock (Cambridge, 1982), and J. Kraye, "Moral philosophy", in The Cambridge history of Renaissance philosophy, ed. by C. B. Schmitt et al. (Cambridge, 1988), 303-86, pp. 360-74.

12. L. Einstein, The Italian Renaissance in England (New York, 1902), chs 1-2; F. Caspari, Humanism and the social order in Tudor England (Chicago, 1954), esp. pp. 10-14, 80, 13652; R. Kelso, The doctrine of the English gentleman in the sixteenth century (Urbana, Ill., 1929), esp. pp. 111-48.

13. George Pettie, "Preface" to Stefano Guazzo, The civile conversation of M. Steeven Guazzo, trans. by George Pettie and Bartholomew Young, ed. by Sir Edward Sullivan (2 vols, London, 1925; orig. publ. in Italian in 1574 and in English in 1581, 1586), i, 8-9; see also L. Stone, The crisis of the aristocracy 1558-1641 (Oxford, 1965), 672, and, for the general humanist stress on education for the nobility, see Q. Skinner, The foundations of modern political thought (2 vols, Cambridge, 1978), i, 241-3.

14. Baldessare Castiglione, The book of the courtier, trans. by C. S. Singleton (Garden City, N.Y., 1959; orig. publ. 1528; orig. English trans. 1561), 67.

15. Shakespeare, Hamlet, III, i.

16. Translator's preface to Pierre Gassendi, The mirrour of true nobility and gentility, trans. by

\section{Provided by the NASA Astrophysics Data System}


W. Rand (London, 1657), sig. A4 (quoted in J. M. Levine, Dr. Woodward's shield: History, science, and satire in Augustan England (Berkeley, Calif., 1977), 120), and idem, Humanism and history: Origins of modern English historiography (Ithaca, N.Y., 1987), 86 (for Gassendi) and 126-31 (for education and English humanism generally). This latter text was brought to my attention (by David Philip Miller) after the present paper was substantially completed; but see chs 3-7 for excellent materials relating to my theme.

17. James Cleland, The instruction of a young noble-man (Oxford, 1612), 134-9.

18. The rich cabinet furnished with varieties of excellent discriptions, exquisite characters, witty discourses, and delightfull histories, deuine and morrall ... wherevnto is annexed the epitome of good manners, extracted from Mr. Iohn de la Casa, ... (London, 1616), 76r.

19. Richard Braithwait, The English gentleman (London, 1630), sig. Nnnr. For Puritan views of bookish learning, see J. Morgan, Godly learning: Puritan attitudes towards reason, learning, and education, 1560-1640 (Cambridge, 1986), esp. p. 71: “The greatest danger of learning ... was that it would become an end in itself, the focus of the scholar's endeavour, not subordinated to godly utility."

20. Henry Peacham, The complete gentleman ..., ed. by V. B. Heltzel (Ithaca, N.Y., 1962; orig. publ. 1622), 28-29, 145. On self-fashioning, see S. Greenblatt, Renaissance self-fashioning: From More to Shakespeare (Chicago, 1980). On Peacham's place in the English culture of virtuosity, see W. E. Houghton, Jr, "The English virtuoso in the sev'nteenth century", Journal of the history of ideas, iii (1942), 51-73, 190-219, esp. p. 67. On the Arundel circle of virtuosi, see Levine, Humanism and history (ref. 16), 83-87, and D. Howarth, Lord Arundel and his circle (New Haven, Conn., 1985).

21. Stone, op. cit. (ref. 13), 672-7; Caspari, op. cit. (ref. 12), 5-13; Kelso, op. cit. (ref. 12), 113-14; W. G. Zeeveld, Foundations of Tudor policy (Westport, Conn., 1981); and see J. H. Hexter, "The education of the aristocracy in the Renaissance", in idem, Reappraisals in history: New views on history and society in early modern Europe, 2nd edn (Chicago, 1979), 45-70, pp. 61-65.

22. See, e.g., M. H. Curtis, Oxford and Cambridge in transition 1558-1642: An essay on the changing relations between the English universities and English society (Oxford, 1959); L. Stone, "The educational revolution in England, 1560-1640", Past and present, xxviii (1964), 41-80; idem, "The size and composition of the Oxford student body 1580-1910", in The university in society, ed. by L. Stone (2 vols, Princeton, N.J., 1974), i, 3-110; J. McConica, "Scholars and commoners in Renaissance Oxford", in ibid., i, 151-81; H. Kearney, Scholars and gentlemen: Universities and society in pre-industrial Britain 1500 1700 (Ithaca, N.Y., 1970); Morgan, op. cit. (ref. 19), ch. 11.

23. The phrase about "seminaries" is from J. Bass Mullinger, The University of Cambridge (3 vols, Cambridge, 1873-1911), ii, 250; the latter phrase is from Curtis, op. cit. (ref. 22), 56 (cf. 61, 82). For statistics, see Stone, "Size and composition" (ref. 22), and McConica, op. cit. (ref. 22).

24. Hexter, op. cit. (ref. 21), 50.

25. Kearney, op. cit. (ref. 22), 23-25; Stone, "Educational revolution" (ref. 22), 70.

26. Quoted in Stone, "Educational revolution" (ref. 22), 76.

27. Quoted in Hexter, op. cit. (ref. 21), 50.

28. Curtis, op. cit. (ref. 22), 128-44; see also Kearney, op. cit. (ref. 22), 38-39; Stone, "Educational revolution" (ref. 22), 70.

29. John Earle, Microcosmographie, facsimile edn of autograph manuscript (Leeds, 1966; comp. 1628), f. 81.

30. Seth Ward, Vindiciae academiarum (Oxford, 1654), 50; see also M. Feingold, The mathematicians' apprenticeship: Science, universities and society in England, 1560-1640 (Cambridge, 1984), 30.

\section{Provided by the NASA Astrophysics Data System}


31. Stone, op. cit. (ref. 13), 674.

32. Hexter, op. cit. (ref. 21), 46-49.

33. Quoted in Stone, "Educational revolution" (ref. 22), 74. For relevant statistics, see McConica, op. cit. (ref. 22); Stone, "Size and composition" (ref. 22); Hexter, op. cit. (ref. 21), 54.

34. For the "explosion", see Stone, op. cit. (ref. 13), 676; Cecil quoted in Kearney, op. cit. (ref. 22), 25 (see also pp. 26-30 and Curtis, op. cit. (ref. 22), 129-31, 135, 143-4).

35. For the careers of university graduates, see Hexter, op. cit. (ref. 21), 55-56; for universities as vehicles of social mobility, see Kearney, op. cit. (ref. 22), 33, and Curtis, op. cit. (ref. 22), 271; for remarks on the particular effects of university residence on commitment to science, see R. G. Frank, Jr, "Science, medicine, and the universities of early modern England: Background and sources", History of science, xi (1973), 194-216, 239-69, pp. 198-9. A more fine-grained account than can be offered here would discuss the learned professions (and trade) as occasional repositories of the gentry's younger sons, the role of the universities in facilitating such moves, and the consequences of a professional career for gentle status; see, e.g., P. Earle, The making of the English middle class: Business, society and family life in London, 1660-1730 (London, 1989), esp. 60-75, 88-89. And, for the possibility of making it to a gentleman's identity through a medical career in late eighteenth century England, see especially R. Porter, "William Hunter: A surgeon and a gentleman", in William Hunter and the eighteenth-century medical world, ed. by W. F. Bynum and R. Porter (Cambridge, 1985), 7-34, esp. pp. 29-31.

36. McConica, op. cit. (ref. 22); Stone, "Size and composition" (ref. 22). The distinction between gentlemen and scholars was (and to varying extents remains) visible in college costume.

37. For career patterns of university fellows in the seventeenth and eighteenth centuries, see $\mathbf{G}$. Holmes, Augustan England: Professions, state and society, 1680-1730 (London, 1982), 36-40. Fellowships were normally held for ten years after taking the B.A., while the graduate was awaiting a college living, at which point they would be resigned for a clerical career. But fellows holding professorships or readerships were in a separate category of career academics, especially those content to remain celibate.

38. For a fuller account, see S. Shapin, "The mind is its own place': Science and solitude in seventeenth-century England", Science in context, iv (1991), 143-70, pp. 148-50.

39. The opposed attributes of 'scholar' and 'gentleman' were frequently inscribed within the standard literary form of the collection of 'characters' - brief sketches of the virtues and typical behaviours of different social types ('the merchant', 'the mathematician', 'the pedant', 'the zealot', 'the citizen', etc.). The genre was inherited from Antiquity (esp. Theophrastus's Characters), and early modern practitioners included inter alia Jean de la Bruyère, John Selden, Samuel Butler, John Earle, and the anonymous author of The rich cabinet. Thus, the literate classes had readily available to them standardized portrayals of the supposed attributes of gentlemen and men of learning.

40. E.g., B. T. Moran, "Princes, machines and the valuation of precision in the sixteenth century", Sudhoffs Archiv, 1xi (1977), 209-28; idem, "Science at the court of Hesse-Kassel: Informal communication, collaboration and the role of the prince-practitioner in the sixteenth century", Ph.D. thesis, University of California at Los Angeles, 1978; R. S. Westman, "The astronomer's role in the sixteenth century: A preliminary study", History of science, xviii (1980), 105-47; M. Biagioli, "The social status of Italian mathematicians, 1450-1600", History of science, xxvii (1989), 41-95; idem, "Galileo's system of patronage", History of science, xxviii (1990), 1-62; idem, "Galileo the emblem maker", Isis, lxxxi (1990), 230-58.

41. For antagonism between the knight and the scholar, see Kelso, op. cit. (ref. 12), 111-13. On

\section{Provided by the NASA Astrophysics Data System}


the seventeenth century English universities perpetuating the image of the scholar as cleric, see Kearney, op. cit. (ref. 22), 168-9.

42. Recent accounts of Galileo as court-philosopher depict him using the social ambiguity of his position in ambitious attempts to establish himself as a person of substance and honour, a courtier whose work flattered the prince-patron in a way exactly analogous to the role of other courtiers; see esp. Biagioli, "Galileo's system of patronage" (ref. 40) and idem, "Galileo the emblem maker" (ref. 40). Nevertheless, it remains unclear how that attempt was perceived by his princely patrons and even more uncertain how plausible was the argued association of the life of honour and the philosophical role. For example, much Italian and French courtesy literature specifying who could and could not instigate a duel put scholars, professionals and philosophers outside the well-born community of honour and resentment. Duelling did, however, become more prevalent among the rising classes of seventeenth century England as a way of publicly displaying entitlement to gentle status. See F. R. Bryson, The point of honour in sixteenth-century Italy: An aspect of the life of the gentleman (New York, 1935), 33; V. G. Kiernan, The duel in European history: Honour and the reign of aristocracy (Oxford, 1989), esp. 102-3, 133-4; and F. Billacois, The duel: Its rise and fall in early modern France, trans. by T. Selous (New Haven, Conn., 1990), 26-33 (for contrast between English and French conceptions).

43. Richard Pace, De fructu (Basel, 1517), quoted in Hexter, op. cit. (ref. 21), 46 (cf. Kelso, op. cit. (ref. 12), 113); Rich cabinet (ref. 18), 134v; Cleland, op. cit. (ref. 17), 134-5; Robert Burton, The anatomy of melancholy, ed. by F. Dell and P. Jordan-Smith (New York, 1927; orig. publ. 1628), 273 (see also pp. 266-7). Castiglione (op. cit. (ref. 14), 67) alleged that the French "not only do not esteem, but they abhor letters, and consider all men of letters to be very base; and they think it is a great insult to call anyone a clerk".

44. For discussions of the bases of gentle standing in the English setting, see, for example, $P$. Laslett, The world we have lost (London, 1965), ch. 2; M. James, English politics and the concept of honour 1485-1642 (Oxford, 1978), esp. 58-63; K. Wrightson, English society 1580-1680 (London, 1982), ch. 1.

45. Castiglione, op. cit. (ref. 14), 109, 139 (for decorum); 43-44, 98, 154 (for genteel sprezzatura, or nonchalance, and the avoidance of affectation); 111 (for criticism of displays of melancholia); Elias, op. cit. (ref. 9), i, 80-4 (for courtesy); cf. Giovanni della Casa, Galateo or the book of manners, trans. by R. S. Pine-Coffin (Harmondsworth, 1958; orig. publ. 1558), 93-97. See also Kelso, op. cit. (ref. 12), 83-85 (for greater English stress on civic usefulness compared to Italian emphasis on personal perfection) and 94-96 (for magnanimity). For enthusiasm as "vulgar", see Ustick, op. cit. (ref. 11), 150.

46. Guazzo, op. cit. (ref. 13), i, 56, 114, 164. (In sixteenth and seventeenth century usage, 'conversation' meant not only face-to-face verbal exchange, but all forms of relations involved in living in society.) Among many seventeenth century injunctions to decorum in the courtesy literature, see Cleland, op. cit. (ref. 17), 171-3, 188; [Antoine de Courtin], The rules of civility; or, certain ways of deportment observed amongst all persons of quality ... (London, 1685; orig. publ. in French 1671; orig. English trans. 1673), esp. pp. 4-5. For a survey of the idea of decorum, see F. A. Childs, "Prescriptions for manners in English courtesy literature, 1690-1760, and their social implications", D.Phil. thesis, Oxford University, 1984, esp. pp. 46-59, 65-67, 95, 193-201; Kelso, op. cit. (ref. 12), 83-84; Greenblatt, op. cit. (ref. 20), 162-3; G. C. Brauer, Jr, The education of a gentleman: Theories of gentlemanly education in England, 1660-1775 (New York, 1959), ch. 5.

47. M. F. B. Brocchieri, “The intellectual”, in Medieval callings, ed. by J. Le Goff, trans. by L. G. Cochrane (Chicago, 1988), 180-209, pp. 205-6; H. Trevor-Roper, "Robert Burton and The anatomy of melancholy", in idem, Renaissance essays (Chicago, 1985), 239-74, pp.

\section{Provided by the NASA Astrophysics Data System}


257-8. For Aristotle on melancholy, see Problems, ed. and trans. by W. S. Hett (2 vols, London, 1957), ii, 155 (Book XXX. 10-13).

48. E.g., Burton, op. cit. (ref. 43), 259, 458-60; Guazzo, op. cit. (ref. 13), i, 16-52. For the iconology of scholarly solitude, see, for example, various portrayals of Saints Anthony, Jerome and Augustine (e.g., Fra Filippo Lippi, Catena, Botticelli, Carpaccio, Titian, van Reymerswaele); Vermeer's L'astronome (Louvre); Gerrit Dou's Astronomer by candlelight (Getty Museum); Rembrandt's Philosophe en méditation (Louvre). General comments on the representation of intellectual solitude are in Shapin, op. cit. (ref. 38), 143-7.

49. See, e.g., Shakespeare's usage in Love's labour's lost, III, i ("A domineering pedant o'er the boy") and Twelfth night, III, ii ("like a pedant that keeps a school").

50. Michel Eyquem de Montaigne, "Of pedantry", in The complete essays of Montaigne, trans. by D. M. Frame (Stanford, Calif., 1965; orig. English trans. 1580), 97-106, pp. 98, 100-1.

51. Guazzo, op. cit. (ref. 13), i, 33; Montaigne, op. cit. (ref. 50), 98; Burton, op. cit. (ref. 43), 262; Richard Lingard, $A$ letter of advice to a young gentleman leaving the university concerning his behaviour and conversation in the world, ed. by F. C. Erb (New York, 1907; orig. publ. 1670), 3; Lodowick Bryskett, A discourse of civill life, ed. by T. E. Wright (Northridge, Calif., 1970; orig. publ. 1606), 13. (The Bryskett text is basically a free and synthetic translation of sixteenth century Italian texts by Giraldi, Piccolomini, and Guazzo.) See also an excellent treatment of a Latin comedy called Pedantius, produced at Trinity College, Cambridge in 1581, in Levine, Humanism and history (ref. 16), ch. 5.

52. Roger Ascham, The scholemaster (London, 1570), 5v. On the prevalence of injunctions against too deep a study of mathematics for gentlemen, see Feingold, op. cit. (ref. 30), esp. pp. 29-30, 190-3.

53. Francis Bacon, "Of studies", in The moral and historical works of Lord Bacon, ed. by J. Devey (London, 1852), 136-7.

54. Montaigne, op. cit. (ref. 50), 106.

55. Bryskett, op. cit. (ref. 51), 13.

56. John Evelyn, Publick employment and an active life prefer'd to solitude, and all its appanages ... (London, 1667), 83, 93. For this text as part of a Restoration argument over the active v. contemplative life, see B. Vickers, "Public and private life in seventeenth-century England: The Mackenzie-Evelyn debate", in idem (ed.), Arbeit, Musse, Meditation: Betrachtungen zur 'Vita activa' und 'Vita contemplativa' (Zürich, 1985), 257-78.

57. Samuel Butler, "The abuse of learning: Fragments of a second part", in idem, Satires and miscellaneous poetry and prose, ed. by R. Lamar (Cambridge, 1928), 80.

58. Burton, op. cit. (ref. 43), 261.

59. John Milton, "The seventh prolusion: A speech in defense of learning delivered in the [Christ's] College chapel", trans. by T. R. Hartmann, in The prose of John Milton, ed. by J. M. Patrick (London/New York, 1968; comp. 1632), 15-28, pp. 19-20; for criticism of schoolmen's pedantry, see ibid., 23-24.

60. Sir Henry Wotton, A philosophical survey of education or moral architecture and aphorisms of education, ed. by H. S. Kermode (London, 1938; orig. publ. 1651), 25.

61. Clement Ellis, The gentile sinner, or England's brave gentleman .... Both as he is, and as he should be, 5th edn (Oxford, 1672; orig. publ. 1660), 26.

62. Edward, Lord Herbert of Cherbury, The autobiography, 2nd edn revised, ed. by S. Lee (London, 1906), 26, 35. The history of early modern science still needs a detailed study of the rhetorical and social forms of disputation in the universities.

63. John Milton, "Of education, to Master Samuel Hartlib ...", in idem, Complete poetry \& selected prose (New York, 1950; orig. publ. 1644), 663-76, pp. 666-7. Note the contemporary resonance of 'generous' as pertaining to nobility, the defining characteristic of the 'gentle'.

\section{Provided by the NASA Astrophysics Data System}


64. For Ramism as pragmatic humanism, see A. Grafton and L. Jardine, From humanism to the humanities: Education and the liberal arts in fifteenth- and sixteenth-century Europe (Cambridge, Mass., 1986), ch. 7; for the English Ramist reform programme, see Kearney, op. cit. (ref. 22), ch. 3; for Paracelsian-sectarian attacks on the universities, see ibid., ch. 7, and A. G. Debus, Science and education in the seventeenth century: The Webster-Ward debate (London, 1970); and, for identification of alchemical discourse as "pedantic", see, e.g., William Gilbert, De magnete, trans. by P. F. Mottelay (New York, 1958; orig. publ. $1600), 1$.

65. Ward, op. cit. (ref. 30), 33.

66. Quoted in R. W. Meyer, Leibnitz and the seventeenth-century revolution, trans. by J. P. Stern (Chicago, 1952), 96. On the urban siting of new chemical practice, see O. Hannaway, "Laboratory design and the aim of science: Andreas Libavius versus Tycho Brahe", Isis, lxxvii (1986), 585-610; $c f$. S. Shapin, "The house of experiment in seventeenth-century England", Isis, lxxix (1988), 373-404.

67. Thomas Hobbes, Behemoth: The history of the causes of the civil wars of England, ed. by W. Molesworth (New York, 1963; orig. publ. 1668), 51, 53, 75.

68. Thomas Hobbes, Leviathan (Harmondsworth, 1968; orig. publ. 1651), $115,117$.

69. A fuller version of this general argument, and the evidence in the following several paragraphs, is in Shapin, op. cit. (ref. 38), 150-5. For a recent appreciation of the humanist contribution to the seventeenth century scientific movement (unfortunately not available to me when the present paper was written), see B. Shapiro, "Early modern intellectual life: Humanism, religion and science in seventeenth-century England", History of science, xxix (1991), 45-71.

70. Francis Bacon, "The advancement of learning", in The philosophical works of Francis Bacon, ed. by J. Spedding, R. L. Ellis and D. D. Heath (5 vols, London, 1857-8), iii, 253-491, pp. 268-71, 313. Bacon here rhetorically played with the etymologically pure meaning of pedants as "teachers and preceptors". For a parallel citation of philosopher-princes, see Milton, op. cit. (ref. 59), 21, and, for a general seventeenth century tendency to posit a Golden Age of gentlemen-scholars, see Brauer, op. cit. (ref. 46), 59.

71. Thomas Elyot, The boke named the governour (London, 1907; orig. publ. 1531), 51-52, 207; see also Skinner, op. cit. (ref. 13), i, 243.

72. Bacon, op. cit. (ref. 70), 273, 277, 280, 314; see also idem, op. cit. (ref. 53), 136.

73. Bacon, op. cit. (ref. 70), 282-95. On the Baconian reforms of natural philosophy as civic humanism, see J. Martin, "Knowledge is power': Francis Bacon, the state, and the reform of natural philosophy", Ph.D. thesis, Cambridge University, 1988, esp. chs. 4-5; also M. E. Prior, "Bacon's man of science", in Roots of scientific thought, ed. by P. P. Wiener and A. Noland (New York, 1957), 382-9.

74. The study of gentlemanly norms and conduct in the early Royal Society has developed rapidly in recent years. In the paragraphs below I offer new materials, as well as drawing upon my own previously published work and excellent studies by Peter Dear, Simon Schaffer, J. V. Golinski, Robert Iliffe and others: see especially S. Shapin, "Pump and circumstance: Robert Boyle's literary technology", Social studies of science, xiv (1984), 481-519, esp. pp. 502-7 (on "manners in dispute"); idem, "O Henry [essay review of Oldenburg, Correspondence]", Isis, lxxviii, 417-24; idem, op. cit. (ref. 66); idem, "Who was Robert Hooke?", in Robert Hooke: New studies, ed. by M. Hunter and S. Schaffer (Woodbridge, Suffolk, 1989), 253-85; idem, "The invisible technician", American scientist, lxxvii (1989), 554-63; S. Shapin and S. Schaffer, Leviathan and the air-pump: Hobbes, Boyle, and the experimental life (Princeton, N.J., 1985), chs 2, 4, 6; S. Schaffer, "Making certain", Social studies of science, xiv (1984), 137-52; P. Dear, "Totius in verba: Rhetoric and authority in the early Royal Society", Isis, lxxvi (1985), 145-61; J. V. Golinski,

\section{Provided by the NASA Astrophysics Data System}


"Robert Boyle: Scepticism and authority in seventeenth-century chemical discourse", in The figural and the literal: Problems of language in the history of science and philosophy, 1630-1800, ed. by A. E. Benjamin, G. N. Cantor and J. R. R. Christie (Manchester, 1987), 58-82; idem, "A noble spectacle: Research on phosphorus and the public cultures of science in the early Royal Society", Isis, $1 \mathrm{xxx}$ (1989), 11-39; R. C. Iliffe, " "The idols of the temple': Isaac Newton and the private life of anti-idolatry", Ph.D. thesis, Cambridge University, 1989; idem, " 'In the warehouse': Privacy, property and priority in the early Royal Society", unpublished typescript (1991).

75. Detailed analyses of the Society's social composition indicate the predominance of the gentry and aristocracy, and, despite much utilitarian rhetoric, the paucity of merchants and tradesmen: M. Hunter, The Royal Society and its Fellows 1660-1700: The morphology of an early scientific institution (Chalfont St Giles, Bucks, 1982), 5 (quoting letter from Francis Vernon to Henry Oldenburg, 1 May 1669). Of course, my argument about the advertised suitability of the new practice for gentlemen does not necessarily depend upon any given statistical state of affairs concerning the Society's social composition, though, as I shall show, a striking exemplar of the aristocratic experimental philosopher provided resources for public legitimization.

76. Thomas Sprat, The history of the Royal Society of London (London, 1667), 404-9, 417.

77. Ibid., 331-2. For an account of attitudes towards traditional learning in the early Royal Society, see M. Hunter, Science and society in Restoration England (Cambridge, 1981), ch. 6.

78. Quoted in M. Hunter, John Aubrey and the realm of learning (New York, 1975), 41.

79. Joseph Glanvill, Scepsis scientifica: or, confest ignorance, the way to science (London, 1885; orig. publ. 1665), pp. liii-liv, lix-lx.

80. Sprat, op. cit. (ref. 76), 26-27; for melancholy see also pp. 16-17, 21, 336, 345, 417.

81. Shapin, "Pump and circumstance" (ref. 74), esp. pp. 502-7; idem, op. cit. (ref. 66), esp. pp. $395-9$.

82. Glanvill, op. cit. (ref. 79), 201-2; for Scholasticism as litigious and as the philosophy of base and servile men, see also 136-42, 196-8. Cf. idem, Essays on several important subjects in philosophy and religion (London, 1676), 31-32; idem, Plus ultra: or, the progress and advancement of knowledge, since the days of Aristotle ... (London, 1668), 148-9.

83. Glanvill, op. cit. (ref. 79), pp. lix-lx. Glanvill seems to have been unusually attuned to the ideal conjunction between knowledge, piety, and manners. In his disputes with the Aristotelian cleric Richard Crosse, Glanvill took his adversary to task for conduct "so little agreeing with the Discretion of a Wiseman, the Charity of a Christian, or the Civility of a Gentleman" (Plus ultra (ref. 82), "Preface", sig. [A7]). For the Glanvill-Crosse controversy, see J. R. Jacob, Henry Stubbe, radical Protestantism and the early Enlightenment (Cambridge, 1983), 78-84.

84. On Boyle's social standing and predicament during the Civil War years, see J. R. Jacob, Robert Boyle and the English Revolution: A study in social and intellectual change (New York, 1977), ch. 2, though the stress there on Boyle's sharp break with the main lines of Renaissance ethical theory now seems overstated. The major source for Boyle's early moral and social views is now The early 'Essays' and 'Ethics' of Robert Boyle, ed. by J. T. Harwood (Carbondale, Ill., 1991).

85. The claim that Christianity underwrote commitment to the common good was widespread in English Puritan circles, and was forcefully expressed by Bacon:

... never in any age has there been any philosophy, sect, religion, law, or other discipline, which did so highly exalt the good which is communicative, and depress the good which is private and particular, as the Holy Christian Faith. ... [I]t decides

\section{Provided by the NASA Astrophysics Data System}


the question touching the preferment of the contemplative or active life ... (Francis Bacon, "De augmentis scientiarum", in Philosophical works (ref. 70), v, 7-8).

For Christianity and civic responsibility among the English gentry, see Kelso, op. cit. (ref. 12), 57; Brauer, op. cit. (ref. 46), 15-16; M. Walzer, The revolution of the saints: $A$ study of the origins of radical politics (Cambridge, Mass., 1965), ch. 7.

86. Here the Englishness of this pattern can be stressed, since in no other country was Christian piety so widely (if hardly universally) associated with an idea of gentility; see, e.g., Ustick, op. cit. (ref. 11), 154-63. Moreover, English commentators themselves routinely insisted upon the moral integrity of the English gentleman compared to his French and Italian counterparts; see, e.g., Einstein, op. cit. (ref. 12), ch. 4; idem, Tudor ideals (London, 1921), 69; Childs, op. cit. (ref. 46), 89-93; Lingard, op. cit. (ref. 51), 22-23.

87. Glanvill, Plus ultra (ref. 82), 93.

88. Gilbert Burnet, "Character of a Christian philosopher, in a sermon preached January 7. 1691-2, at the funeral of the Hon. Robert Boyle", in idem, Lives, characters, and an address to posterity, ed. by J. Jebb (London, 1833), 325-76, quoting pp. 333, 348, 352, 360-1, 367. For details of Boyle's moral relations with Burnet, see M. Hunter, "Alchemy, magic and moralism in the thought of Robert Boyle", British journal for the history of science, xxiii (1990), 387-410.

89. [William Ramesey], The gentlemans companion: or, a character of true nobility, and gentility ... by a person of quality ... (London, 1676; comp. 1669), 15. For arguments against 'dogmatism' and 'contentious disputes' in general, see ibid., 71-74.

90. Gilbert Burnet, Thoughts on education, ed. by J. Clarke (Aberdeen, 1914; comp. c. 1668), 61, 70.

91. William Wotton, Reflections upon ancient and modern learning (London, 1694), 353-5. For recent overviews of the "ancients" $v$. "moderns" debate, see Hunter, op. cit. (ref. 77), 159-61, and Levine, Humanism and history (ref. 16), ch. 6, and, for imputations of pedantry in those controversies, see R. Iliffe, "Author-mongering: The 'editor' between producer and consumer", unpubl. typescript (1991), 34-35.

92. Ramesey, op. cit. (ref. 89), 131-2. Also on the list were works of Copernicus, Galileo, Descartes, Henry More, William Harvey, Walter Charleton, Thomas Willis, Kenelm Digby, Thomas Browne, Joseph Glanvill, and Robert Hooke - "his Micrography; and the rest of our New Experiments".

93. Daniel Defoe, The compleat English gentleman, ed. by K. D. Bülbring (London, 1890; orig. comp. c. 1728-29), 228, 191-2, 65, 69. Defoe also exempted some few other English gentlemen from the general indictment: England has "some of the greatest men that ever the world produced, exquisite in science, compleat in the politest learning, bright in witts ...; no science, no commendable study, no experimentall knowledge, no humane attaintment, but they excell in ..." (ibid., 89-90).

94. Anon. editor's note in The original works of William King, LL.D (3 vols, London, 1776), ii, 98.

95. Thomas Zouch (ed.), Walton's lives (York, 1796), 480n.-481n., quoted in editor's note in Burnet, op. cit. (ref. 88), 367n.

96. See, e.g., R. Porter, English society in the eighteenth century (Harmondsworth, 1982), esp. ch. 6. In this connection it is relevant that the English universities in the period from the Restoration to the mid-eighteenth century were experiencing a decline in their student numbers and fortunes. As Porter notes, "It was grinding tutors and slumbrous pedants who made an academic career in the colleges: the great scholars of Georgian England ... were not dons" (ibid., 179). On the conservatism of the universities and on their continuing significance as clerical seminaries $c$. 1700, see Kearney, op. cit. (ref. 22), ch. 10;

\section{Provided by the NASA Astrophysics Data System}


Holmes, op. cit. (ref. 37), 34-42; and J. Gascoigne, Cambridge in the age of the Enlightenment: Science, religion and politics from the Restoration to the French Revolution (Cambridge, 1989), esp. pp. 17-19.

97. Defoe, op. cit. (ref. 93), 203; see also Brauer, op. cit. (ref. 46), 67.

98. Lingard, op. cit. (ref. 51), 9; De Courtin, op. cit. (ref. 46), 28-29; Adam Petrie, Rules of good deportment, or of good breeding (Edinburgh, 1720), 46, 58. For surveys of attitudes towards learning and pedantry in the late seventeenth century courtesy literature, see Childs, op. cit. (ref. 46), 78, 215-18; Brauer, op. cit. (ref. 46), ch. 3.

99. Samuel Butler, Characters and passages from note-books, ed. by A. R. Waller (Cambridge, 1908), 136-7.

100. Samuel Butler, "Satyr upon the imperfection and abuse of human learning part 1st", in idem, op. cit. (ref. 57), 68.

101. Obadiah Walker, Of education especially of young gentlemen (Oxford, 1673), 112, 249-51; see also Brauer, op. cit. (ref. 46), 66-68; Hunter, op. cit. (ref. 77), 160.

102. William Temple, "An essay upon the ancient and modern learning", in The works of Sir William Temple, Bart. (4 vols, London, 1814; orig. publ. 1690), iii, 444-86, pp. 484-6. And for a late seventeenth century critique of humanistic arrogance and humanists' contribution to pedantry, see Jean LeClerc, Parrhasiana, or, thoughts upon several subjects (London, 1700), 181-3 (quoted in B. C. Southgate, "No other wisdom'? Humanist reactions to science and scientism in the seventeenth century", The seventeenth century, v (1990), 71-92, p. 87).

103. Anthony Ashley Cooper, 3rd Earl of Shaftesbury, Characteristics of men, manners, opinions, times, ed. by J. M. Robertson (2 vols in 1, Indianapolis, Ind., 1964; orig. publ. 1711), i, 53, 81, 88, 196, 214.

104. The spectator, no. 105, 30 June 1711, in The spectator, ed. by D. F. Bond (5 vols, Oxford, 1965), i, 436-8.

105. Joseph Addison and Richard Steele, The tatler, ed. by G. A. Aitken (4 vols, London, 1898), i, 148 (17-19 May 1709); 176 (26-28 May 1709); iv, 245-7 (28-31 October 1710); see also (on pedants) iii, 235 (11-13 April 1710); iv, 49 (25-27 July 1710).

106. Samuel Johnson, The rambler, ed. by W. J. Bate and A. B. Strauss (vols iii-v of 15 vols, Works, New Haven, Conn., 1958-85), v, 36-37 (10 April 1750); 151-3 (12 November 1751); see also (on scholarly seclusion and incivility) v, 70-75 (17 September 1751) and v, 176-81 (3 December 1751).

107. Philip Dormer Stanhope, Earl of Chesterfield, Letters to his son and others (London, 1984; comp. c. 1746-53), 16, 71, 136, 145, 184, 191, 263, 270-1.

108. John Locke, Some thoughts concerning education (Cambridge, 1899; orig. publ. 1693), 74, 129, 153; see also Brauer, op. cit. (ref. 46), 59, and Frank op. cit. (ref. 35), 253.

109. Locke, op. cit. (ref. 108), 166, 169-70; see also L. Stone, "Practical wisdom for élite boys", Times literary supplement, 2-8 March 1990, 229-30. For the central importance of Boyle's corpuscular and mechanical philosophy in Locke's work, see P. Alexander, Ideas, qualities and corpuscles: Locke and Boyle on the external world (Cambridge, 1985). For reasons indicated above I cannot wholly agree with James Secord's judgement that in Some thoughts concerning education "Locke had strongly emphasized the need for young gentlemen to obtain a cultured acquaintance with science": J. A. Secord, "Newton in the nursery: Tom Telescope and the philosophy of tops and balls, 1761-1838", History of science, xxiii (1985), 127-51, p. 131, though Secord's paper is a brilliant analysis of scientific texts for children, especially of "the professional and mercantile middling orders", in this period; see particularly perceptive comments on the changing depiction of science vis-à-vis the aristocracy from the middle of the eighteenth to the middle of the nineteenth century (pp. 143-5).

110. E.g., R. H. Syfret, "Some early reactions to the Royal Society", Notes and records of the 
Royal Society, vii (1950), 207-58; idem, "Some early critics of the Royal Society", ibid., viii (1950), 20-64; M. H. Nicolson, Science and imagination (Ithaca, N.Y., 1956); and the synoptic treatment in Hunter, op. cit. (ref. 77), esp. ch. 6. R. B. Schwartz, Samuel Johnson and the new science (Madison, Wisc., 1971), ch. 4.

111. Wotton, op. cit. (ref. 91), "Conclusion", as quoted in Syfret, "Early critics", op. cit. (ref. 110), 44; for sensitivity to the power of the "wits" "ridicule, see also Sprat, op. cit. (ref. 76), 417-19. And, for the point of view of an "ancient" scholar, see Temple, op. cit. (ref. 102), 485-6.

112. Butler, "Pædants", in idem, op. cit. (ref. 57), 166.

113. Butler, "The elephant in the moon", in ibid., 3-30; see also Nicolson, op. cit. (ref. 110), 170-1.

114. Butler, op. cit. (ref. 57), 33. Of course, according to Pepys, Charles II also wanted to know what his philosophers had done apart from weighing the air, and Thomas Shadwell repeated what must by then have been a very stale joke in The virtuoso of 1676 . For the King's view of the Royal Society, see, e.g., W. E. K. Middleton, "What did Charles II call the Fellows of the Royal Society?", Notes and records of the Royal Society, xxxii (1977), 13-17, and Hunter, op. cit. (ref. 77), 130-1; for Shadwell, see The virtuoso, ed. by M. H. Nicolson and D. S. Rodes (Lincoln, Neb., 1966), 110 (V.ii); Syfret, "Early critics", op. cit. (ref. 110), 54-55, 58-59.

115. Shadwell, op. cit. (ref. 114), 22 (I.i), 68 (III.iii). For the background to this play, see Nicolson and Rodes, op. cit. (ref. 114), "Introduction", pp. xi-xxvi. Historians have claimed that Gimcrack was modelled on Robert Hooke. Most plausibly, he is a pastiche of a number of well-known Royal Society figures. There are certainly large dollops of Boyle in the character: his title (Sir Nicholas) points towards an aristocratic model, and his Puritanical piety closely follows Boyle's. There are also quite specific references in the play to Boyle's published work.

116. William King, "Useful transactions in philosophy, and other sorts of learning ...", in idem, op. cit. (ref. 94), ii, 57-178 (orig. publ. 1709), pp. 98-99 (for Boyle's phosphorus); 103-14, 121-5 (for Leeuwenhoek); 135 (for dregs); idem, "A journey to London, in the year 1698. After the ingenious method of that made by Dr. Martin Lister to Paris ...", ibid. (orig. publ. 1699), i, 198 (for cats).

117. John Wilkins, as quoted in Syfret, "Early critics", op. cit. (ref. 110), 55; see also Nicolson, op. cit. (ref. 110), ch. 6; J. T. Harwood, "Rhetoric and graphics in Micrographia", in Robert Hooke: New studies, ed. by M. Hunter and S. Schaffer (Woodbridge, Suffolk, 1989), 11947, esp. pp. 139, 142; and S. Shapin, "Who was Robert Hooke?", in ibid., 253-85, esp. pp. 277-8.

118. The tatler (ref. 105), iii, 31 (10-12 January 1709/10); iv, 110 (24-26 August 1710).

119. Ibid., iv, 209-10 (10-12 October 1710). For satire of "Sir Nicholas Gimcrack", see ibid., 112$13,133-8$, and for additional criticism of Royal Society science as trivial and useless, see ibid., 171-2, 320-6.

120. [Mary Astell or Judith Drake?], An essay in defense of the female sex in which are inserted the character of a pedant, a squire, a beau, a virtuoso (London, 1696), quoted in Levine, Dr. Woodward's shield (ref 16), 125. Here, as elsewhere, critics often had in view specific individuals, whose actual behaviour at times was more than equal to any caricature. John Woodward was very widely pointed to as the pattern of a vain and pompous virtuoso; William King reserved special odium for Martin Lister and Hans Sloane; and, as I note below, Butler, Swift and others had merry sport with Boyle's pious philosophy. For Woodward, see ibid., chs 5-7; for female virtuosa, see Nicolson, op. cit. (ref. 110), 186-93. Scientific culture in specifically female society has, arguably, been treated more fully in recent years than in a specifically masculine context; see, among many examples, $P$. Phillips, The scientific lady: A social history of woman's scientific interests 1520-1918

\section{Provided by the NASA Astrophysics Data System}


(London, 1990); A. B. Shteir, "Linnaeus's daughters: Women and British botany", in Women and the structure of society: Selected research from the Fifth Berkshire Conference on the History of Women, ed. by B. J. Harris and J. K. McNamara (Durham, N.C., 1984), 67-73.

121. Shaftesbury, op. cit. (ref. 103), ii, 253.

122. Levine, Dr. Woodward's shield (ref. 16), 125 (my emphases).

123. Shaftesbury, op. cit. (ref. 103), i, 193-6; cf. Butler, op. cit. (ref. 99), 276: "The end of all Knowledge, is to understand what is Fit to be don; For to know what has been, and what is, and what may be, dos but tend to that."

124. Syfret, "Early critics" (ref. 110), 56-58; Houghton, op. cit. (ref. 20). For an overview of the new science in relation to its alleged utility, see Hunter, op. cit. (ref. 77), ch. 4.

125. Shadwell, op. cit. (ref. 114), 47 (II.ii).

126. Ibid., 114, 119 (V.ii, V.iii).

127. Temple, "Some thoughts upon reviewing the essay of ancient and modern learning", in idem, op. cit. (ref. 102), iii, 487-518, pp. 516-17 (comp. c. 1695). For an appreciation of the seventeenth century literary and moral case against scientistic ambition, see Southgate, op. cit. (ref. 102).

128. Jonathan Swift, Gulliver's travels, ed. by M. K. Starkman (New York, 1962; comp. 1721-25; orig. publ. 1735), 175; see also Nicolson, op. cit. (ref. 110), 110-54, 193-9, and J. R. R. Christie, "Laputa revisited", in Nature transfigured: Science and literature, 1700-1900, ed. by J. R. R. Christie and S. Shuttleworth (Manchester, 1989), 46-60.

129. The tatler (ref. 105), iv, 134 (5-7 September 1710).

130. King, "The transactioneer", in idem, op. cit. (ref. 94), ii, 1-56 (orig. publ. 1700), esp. pp. 16, 32, 49; idem, "Useful transactions" (ref. 116), passim; Temple, "Some thoughts" (ref. 127), 516-17.

131. Butler, "A virtuoso", in idem, op. cit. (ref. 99), 81; cf. Levine, Dr. Woodward's shield (ref. 16), 124; Syfret, "Early critics" (ref. 110), 60.

132. The tatler (ref. 105), iv, 326 (7-9 December 1710).

133. Temple, op. cit. (ref. 127), 517.

134. King, "The transactioneer" (ref. 130), 17.

135. Shadwell, op. cit. (ref. 114), 111 (V.ii). Cf. Robert Boyle, "Some observations about shining flesh, both of veal and of pullet ...", in idem, Works, ed. by T. Birch (6 vols, London, 1772), iii, 651-5 (orig. publ. 1672).

136. Shadwell, op. cit. (ref. 114), 19 (I.i).

137. Butler, "An occasional reflection on Dr. Charleton's feeling a dog's pulse at GreshamCollege. By R. B. Esq.”, in idem, op. cit. (ref. 57), 341-3; Jonathan Swift, “A meditation upon a broom-stick: According to the style and manner of the Honourable Robert Boyle's Meditations. Written in the year 1703", in idem, The prose works, ed. by H. Davis (14 vols, Oxford, 1939-69), i, 239-40; letter from Duke of Buckingham to Earl of Rochester, July 1677, in The letters of John Wilmot, Earl of Rochester, ed. by J. Treglown (Chicago, 1980), 146-7. See also Shadwell, op. cit. (ref. 114), 18 (I.i) for Boyle's meletetiques (or meditational techniques).

138. Shaftesbury, op. cit. (ref. 103), i, 50-52; cf. J. Redwood, Reason, ridicule and religion: The age of Enlightenment in England 1660-1750 (Cambridge, Mass., 1976), esp. pp. 39, 84-86.

139. Butler, "A philosopher", in idem, op. cit. (ref. 99), 57-58. The reference is to Walter Charleton's text of 1654 .

140. Swift, op. cit. (ref. 128), 161-2.

141. For structural conditions bearing on the expectation of "militant combativeness" in the world of learning, see, for example, A. R. Hall, Philosophers at war: The quarrel between Newton and Leibniz (Cambridge, 1980), esp. pp. 2-7. 
142. Levine, Dr. Woodward's shield (ref. 16), esp. pp. 81-91. In a later period, Sir John Hill served as a publicly recognized exemplar of a "dizzard" naturalist; see G. S. Rousseau, "John Hill, universal genius manqué: Remarks on his life and times, with a checklist of his works", in J. A. L. Lemay and G. S. Rousseau (eds), The Renaissance man in the eighteenth century (Los Angeles, 1978), 45-129.

143. Both quoted in Levine, Dr. Woodward's shield (ref. 16), 123-4.

144. Swift, op. cit. (ref. 128), 161.

145. [William Darrell], The gentleman instructed, in the conduct of a virtuous and happy life .... Written for the instruction of a young nobleman ..., 8th edn (London, 1723; orig. publ. 1704-12), 15. This general form of injunction was evidently quite standard in the contemporary courtesy literature; see, e.g., Petrie, op. cit. (ref. 98), as quoted on p. 301 above.

146. Johnson, The rambler (ref. 106), v, 71-75 (17 September 1751).

147. D. E. Allen, The naturalist in Britain: A social history (London, 1976), esp. chs 2-3; R. S. Porter, "Science, provincial culture and public opinion in Enlightenment England", British journal for eighteenth-century studies, iii (1980), 20-46; David Philip Miller, "The Royal Society of London 1800-1835: A study of the cultural politics of scientific organization", Ph.D. thesis, University of Pennsylvania, 1981, 42-46; Levine, Humanism and history (ref. 16), chs 3-4; S. A. E. Mendyk, 'Speculum Britanniae': Regional study, antiquarianism, and science in Britain to 1700 (Toronto, 1989), esp. pp. 239-44.

148. Examples are R. E. Schofield, The Lunar Society of Birmingham: A social history of provincial science and industry in eighteenth-century England (Oxford, 1963); A. Thackray, "Natural knowledge in cultural context: The Manchester model", American historical review, lxxix (1974), 672-709; Metropolis and province: Science in British culture, 1780-1850, ed. by I. Inkster and J. Morrell (London, 1983).

149. By the late nineteenth century, scientific naturalists like John Tyndall were once more urging support of science "Not as a servant of Mammon" but "as the strengthener and enlightener of the mind of man". Gieryn analyses apparently inconsistent repertoires for legitimating science as reflections of "an unyielding tension between basic and applied research", but, more fruitfully, also sees the renewed stress on virtue as a situated rhetorical tool for demarcating a particular strand of science from mere mechanic empiricism (op. cit. (ref. 6), 787).

150. For historically changing social locations of moral authority and technical knowledge, see $T$. W. Heyck, The transformation of intellectual life in Victorian England (London, 1982), ch. 3.

151. S. Schaffer, "Genius in romantic natural philosophy", in Romanticism and the sciences, ed. by A. Cunningham and N. Jardine (Cambridge, 1990), 82-98.

152. R. Yeo, "Genius, method and morality: Images of Newton in Britain, 1760-1860", Science in context, ii (1988), 257-84; Iliffe, "'Idols of the temple" (ref. 74), chs 5-6; Shapin, op. cit. (ref. 38), 155-60.

153. Newman, op. cit. (ref. 3), 180-1; Thomas Carlyle, "Signs of the times", in idem, Selected writings, ed. by A. Shelston (Harmondsworth, 1971), 59-85, esp. pp. 64-71 (orig. publ. 1829).

154. James Moore persuasively argues that Charles Darwin in the years immediately after his removal to Down in 1842 was experimenting with his entitlement to the recognized role as "squarson-naturalist": J. R. Moore, "Darwin of Down: The evolutionist as squarsonnaturalist", in The Darwinian heritage, ed. by D. Kohn (Princeton, N.J., 1985), 435-81, esp. pp. 440-3.

155. Few modern commentators on these matters have been as maliciously perceptive as Simon Raven, e.g., The decline of the gentleman (New York, 1962), 10-11, 180-1. 